\title{
Climate control on late Holocene high-energy sedimentation along coasts of the northeastern Atlantic Ocean
}

\author{
Clément Poirier ${ }^{\mathrm{a}, *}$, Bernadette Tessier ${ }^{\mathrm{a}}$, Eric Chaumillon ${ }^{\mathrm{b}}$ \\ a Morphodynamique Continentale et Côtière, Université de Caen Normandie, CNRS, Caen 14000, France \\ b UMR 7266 LIENSs, CNRS/Université de la Rochelle, 2 rue Olympe de Gouges, La Rochelle 17000, France
}

\section{A R T I C L E I N F O}

\section{Article history:}

Received 13 April 2017

Received in revised form 28 July 2017

Accepted 31 July 2017

Available online 2 August 2017

\section{Keywords:}

Radiocarbon

Meta-analysis

Coastal barrier

HSP

Teleconnection

\begin{abstract}
A B S T R A C T
Abundant sedimentological and geochronological data gathered on European sandy coasts highlight major phases of increased high-energy sedimentation in the North Atlantic Ocean during the late Holocene. Owing to an inconsistent use of the terminology, it is often difficult to determine whether studies have described storm-built or wave-built deposits. Both deposits can be identified by overall similar coarse-grained sedimentary facies, but may provide contradictory paleoenvironmental interpretations. The aim of this study is to address this issue, by analysing a set of published ${ }^{14} \mathrm{C}$ ages recovered from wave-built sediment bodies of the Pertuis Charentais (France). Integration of ${ }^{14} \mathrm{C}$ data highlights seven coarse-grained sedimentation pulses (CSPs) that reflect a synchronous increase in wave-induced sediment supply occurring around 2650, 2420, $1240,970,800,650$ and 450 cal. yr B.P. CSPs can be matched with geochronological data published on other exposed sandy coasts of the western Europe. In first order, CSPs were preserved during phases of decreased storm activity and thus limited coastal erosion in the North Atlantic Ocean from 2700 to 2000 and from 1200 to $600 \mathrm{cal}$. yr B.P. In second order, CSPs occurred during positive NAO and/or negative EA/WR peaks, which are known from previous studies to induce higher waves and to enhance wave-induced sediment transport in the Pertuis Charentais. Chronological boundaries of CSPs could be used as a diagnostic tool to differentiate storm deposits indicative of sudden, episodic very high-energy sedimentation from wave deposits resulting from the sustained action of above-average westerly winds blowing across the North Atlantic Ocean.
\end{abstract}

(C) 2017 Elsevier B.V. All rights reserved.

\section{Introduction}

Sandy coasts represent an important proportion of the world's oceanic shorelines, typically occurring in energetic wave-dominated areas. Over timescales of hours to millennia, the morphological evolution of sandy coasts is determined by a dynamic equilibrium in the budget between sediment supply (resilience) and erosive events (destruction; Masselink and van Heteren, 2014). It is widely acknowledged that individual storm episodes can induce rates of coastal erosion far exceeding those observed during sustained fair weather conditions (Morton and Sallenger, 2003). Owing to the attractiveness of these landscapes, sandy coasts are often densely populated areas (Zhang and Leatherman, 2011). Forecasted acceleration of sea-level rise (Rahmstorf, 2007), combined with changes in wind and wave climate (Dobrynin et al., 2012), might modify

\footnotetext{
* Corresponding author.

E-mail addresses: clement.poirier@unicaen.fr (C. Poirier) bernadette.tessier@unicaen.fr (B. Tessier), eric.chaumillon@univ-lr.fr (E. Chaumillon).
}

sediment budgets on these shorelines, thus putting more coastal populations at risk of storm-surge flooding (Chaumillon et al., 2017).

Abundant sedimentological and geochronological data gathered on European sandy coasts highlight major phases of storminess in the North Atlantic Ocean during the late Holocene. Disagreement between studies remains high, which is related to a great extent to the heterogeneity of sediment records involved. However, we also believe that the term "storminess" in itself is used inconsistently across publications. Some studies use "storminess" to designate the intensity of prevailing westerly winds blowing across the North Atlantic Ocean (e.g. Orme et al., 2015). Here, we use instead "storminess" in the meaning of e.g. Sabatier et al. (2012) or Sorrel et al. (2012), to designate the recurrence of extreme, sudden meteorological events lasting a few hours to days, associated with storm surge and wave runup that have strong potential for coast erosion. Storminess should be interpreted as a measure of the intensity and/or frequency of these morphogenic events that may fluctuate over a given period of time.

Following this definition, periods of increased storminess in the North Atlantic Ocean were shown to be tied to short-lived cooling 
events recorded as ice-rafted debris maxima (IRD; Bond et al., 2001; Sorrel et al., 2012). Temporal variability of the IRD time series displays three dominant oscillations of about 2400, 1450 and 1000 years (Debret et al., 2007). The 2400- and 1000-yr oscillations are associated with long-term changes in solar forcing. The $1450-\mathrm{yr}$ cycle, which is expressed more strongly than the two former since about $6000 \mathrm{cal}$. yr B.P., is likely related to internal variability of the North Atlantic Ocean (Debret et al., 2007; Sorrel et al., 2012) and/or of the Arctic Ocean (Darby et al., 2012). This internal forcing likely drives fluctuations of the subpolar and subtropical gyres that modulate the strength and trajectory of storm tracks in the North Atlantic Ocean (Sorrel et al., 2012). It affects the occurrence of storm events on western European coasts, which have been grouped into five "Holocene Storm Periods" (HSP; Sabatier et al., 2012; Sorrel et al., 2012). The most recent HSP corresponds to the Little Ice Age (LIA), i.e. to the Bond cycle 0 (Bond et al., 2001). Steepening of the meridional temperature gradient during the LIA is frequently invoked as a plausible mechanism needed to trigger stronger storms in the North Atlantic Ocean at that time (Dezileau et al., 2011; Lamb and Frydendahl, 1991; Trouet et al., 2012), in possible conjunction with low-frequency changes in sea surface temperature driving tropical cyclogenesis (van Hengstum et al., 2015).

There is a fundamental dichotomy in the sedimentary expression of HSPs. Onshore, HSPs are associated with the widespread formation of massive aeolian dune fields and coversands stretching along the coasts of western Europe (Alexanderson and Bernhardson, 2016; Bateman and Godby, 2004; Clarke et al., 2002; Clarke and Rendell, 2006; Clemmensen et al., 1996; Clemmensen and Murray, 2006; Clemmensen et al., 2009; Costas et al., 2013, 2012, 2016; Gilbertson et al., 1999; Jelgersma et al., 1995; Nielsen et al., 2016; Sommerville et al., 2007; van Vliet-Lanoë et al., 2016; Wilson and Braley, 1997; Wilson et al., 2004), also recorded as the deposition of thin windblown quartz layers over soils (Jackson et al., 2005) and peat bogs (Björck and Clemmensen, 2004; de Jong et al., 2006, 2007; Kylander et al., 2016; Orme et al., 2015, 2016; Sjögren, 2009; Tisdall et al., 2013). Aeolian activity was initiated during the last glacial termination (Costas et al., 2016) that gave rise to the periglacial "European Sand Belt" (Zeeberg, 2008), the most recent phase of dune formation being the LIA. In marine settings, the sedimentary expression of HSPs is more diverse. A dominant feature is the presence of discrete, millimetre to centimetre thick shelly sand to gravel layers embedded in back-barrier lagoonal successions (Degeai et al., 2015; Dezileau et al., 2011; Sabatier et al., 2008) or in marsh fine-grained sediments (Billeaud et al., 2009), interpreted as the imprint of barrier destruction and sand over wash (Chaumillon et al., 2017). These discrete coarse layers are also recognised offshore, in the wave-influenced outer section of estuaries (Baltzer et al., 2014; Sorrel et al., 2009). Another dominant feature is the detection of discrete erosional discontinuities in estuaries (Billeaud et al., 2009; Tessier et al., 2010) and lagoons (Ferrer et al., 2010), indicative of prolonged phases of sediment remobilisation and/or erosion.

Owing to an inconsistent use of the terminology, it is often difficult to determine whether these studies have described storm or wave deposits. Both have overall similar coarse-grained sedimentary facies, but may provide contradictory palaeoenvironmental interpretations. Storm deposits resulting from sudden meteorological events may be indicative of coastal destruction. Inversely, wave deposits resulting from the sustained action of above-average westerly winds may be indicative of coastal progradation. Accurate stratigraphical and geochronological data, correlated across coasts within the same climatic zone, are therefore needed to better constrain these discrepancies. As described above, the sedimentary expression of HSPs is illustrated by abundant data, but less is known in contrast about the evolution of European sandy coasts between HSPs, in a context of weakened storm intensity and/or frequency. The aim of this study is to address these two issues, by analysing a set of ${ }^{14} \mathrm{C}$ data obtained on coarse-grained sediment bodies of the Pertuis Charentais regressive coastal environment (France), and by comparing results with similar sand bodies in western Europe.

\section{Study area}

The Pertuis Charentais area was chosen because it has received much attention over recent decades, with abundant stratigraphical, sedimentological and geochronological data (Allard et al., 2008, 2010; Bertin et al., 2008; Bertin and Chaumillon, 2006; Billeaud et al., 2005; Chaumillon et al., 2008, 2004; Chaumillon and Weber, 2006; Poirier et al., 2011; Weber et al., 2004a,b). Previous studies have demonstrated the vulnerability of the Pertuis Charentais to storm events (Baumann et al., 2017a,b; Breilh et al., 2014), and its ability to record climate changes of the past centuries to decades (Allard et al., 2008; Poirier et al., 2011, 2017).

\subsection{Geological setting}

The study area is located along the Atlantic Coast of France (Fig. 1A), in Charente Maritime $\left(46^{\circ} \mathrm{N}, 01^{\circ} \mathrm{W}\right)$, and corresponds to the northern boundary of the Aquitaine Basin, at the contact with the Armorican Massif (Fig. 1B; Biteau et al., 2006). Anticlines and synclines formed in the northern part of the Aquitaine basin during the late Cretaceous and Paleocene, in response to compressive deformation of the crystalline basement related to Pyrenean orogeny (Sibuet et al., 2004). Differential erosion of Mesozoic to Cenozoic loose marls and sandstones in synclines during the Pleistocene contributed to the formation of NW-SE incised valleys, which provided a large accommodation space for deposition of Holocene marine and continental sediments (Fig. 1B; Chaumillon et al., 2008; Chaumillon and Weber, 2006; Weber et al., 2004a,b).

\subsection{Geomorphology}

The study area is referred to as the "Pertuis Charentais". The word "pertuis" locally designates the outer marine segment of three main incised valleys (Chaumillon et al., 2008), which extend inland into large low-lying coastal marshes (Breilh et al., 2013). They include, from north to south (Fig. 1B):

- The Pertuis Breton $\left(260 \mathrm{~km}^{2}\right)$ and Poitevin marsh $\left(980 \mathrm{~km}^{2}\right)$, which correspond to the paleo-valleys of the Sèvre Niortaise, Vendée and Lay rivers (Chaumillon and Weber, 2006; Weber et al., 2004a),

- The Pertuis d'Antioche $\left(450 \mathrm{~km}^{2}\right)$ and Rochefort marsh (240 $\mathrm{km}^{2}$ ), which correspond to the paleo-valley of the Charente River (Chaumillon and Weber, 2006; Weber et al., 2004b),

- The Pertuis de Maumusson and Arvert marsh (170 km²), which correspond to the paleo-valley of the Seudre river (Chaumillon et al., 2008). The Pertuis de Maumusson, unlike the two former bounded by rocky shores, is a $1.5 \mathrm{~km}$ wide sedimentary tidal inlet (Bertin et al., 2004).

The Pertuis Charentais seafloor is shallow, with more than $90 \%$ of its total area between 0 and $-20 \mathrm{~m} \mathrm{NGF}$ (French reference vertical datum, zero being mean sea level at Marseille), and $65 \%$ between 0 and $-10 \mathrm{~m}$. Mesozoic bedrock outcrops in the marshes to an altitude

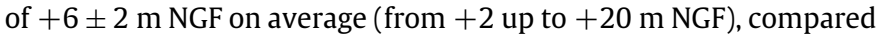
to an average marsh elevation between +1.6 and $+3.4 \mathrm{~m} \mathrm{NGF}$ (Breilh et al., 2013).

\subsection{Wave climate}

The area is affected by semi-diurnal tides ranging from less than $2 \mathrm{~m}$ (neap tides) to more than $6 \mathrm{~m}$ (spring tides), and by waves 


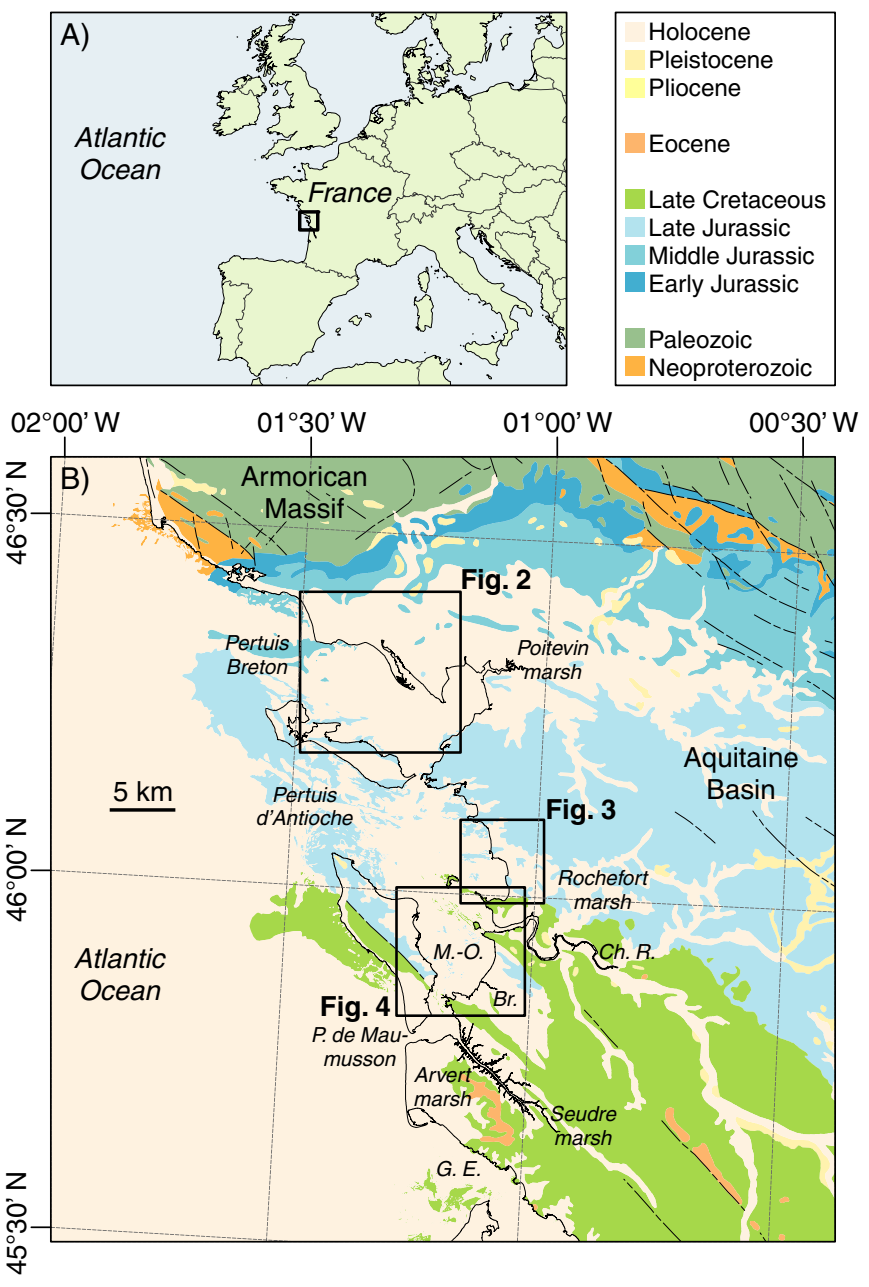

Fig. 1. A, Map of Europe, showing the location of the Pertuis Charentais. B, Simplified continuous land-sea geological map of the area, showing the location of the three study areas. Labels in italics correspond to toponyms cited in the text. M.-O., Marennes-Oléron Bay; Br., Brouage Marsh; Ch. R., Charente River; G. E., Gironde Estuary.

originating from the North Atlantic Ocean. Two main wave climate categories can be distinguished: (1) low to moderate wave conditions (height $\mathrm{Hs}_{1 / 4}=0.8-2.5 \mathrm{~m}$, period $\mathrm{Tp}_{1 / 4}=6-12 \mathrm{~s}$, direction $\operatorname{Dirp}_{1 / 4}=274-292^{\circ}$ ) more frequent during summer and representing $58-69 \%$ of the annual wave climate and (2) energetic wave conditions $\left(\mathrm{Hs}_{1 / 4}=2.5-9.4 \mathrm{~m}, \mathrm{Tp}_{1 / 4}=11-15 \mathrm{~s}\right.$, Dirp $\left.\mathrm{D}_{1 / 4}=265-280^{\circ}\right)$ more frequent in winter and representing $15-27 \%$ of the annual wave climate (Bertin et al., 2008). Owing to complex hydrodynamic and bathymetric interactions within the Pertuis, wave energy along the coast is decayed by almost one order of magnitude relative to offshore conditions (Allard et al., 2008).

At the annual to decadal time scale, the position, strength and trajectory of low-pressure systems across the North Atlantic Ocean is controlled by Northern Hemisphere atmospheric circulation patterns, the most prominent being the North Atlantic Oscillation (NAO; Barnston and Livezey, 1987; Rogers, 1997). The NAO atmospheric circulation pattern, along with the East Atlantic (EA), East Atlantic-West Russia (EA/WR) and Scandinavian (SCAN) patterns, indirectly affects wave height, period and direction in the North Atlantic Ocean (Martínez-Asensio et al., 2016, and references therein). Recent (1948-2014) nearshore wave climate and resulting wave-induced longshore sediment transport have been computed from a high-resolution wave hindcast along the Arçay sand spit (Fig. 3A; Poirier et al., 2017). Within the Pertuis Breton, the NAO and EA/WR patterns respectively account for 25.2 and $20.6 \%$ of the winter (December to February) longshore sediment transport variability, while the contribution of EA pattern is minor (3.6\%) and that of SCAN is not significant. Longshore sediment transport increases with positive NAO and negative EA/WR conditions (Poirier et al., 2017), both being associated with higher offshore and nearshore waves in the area (Martínez-Asensio et al., 2016).

\subsection{Holocene evolution}

Internal architecture, sedimentology and timing of deposition of the Holocene sediment infilling of the outer marine Pertuis Charentais have been extensively investigated with very highresolution seismic surveys ground-truthed by sedimentary cores and ${ }^{14} \mathrm{C}$ dating (Chaumillon et al., 2004; Chaumillon and Weber, 2006; Weber et al., 2004a,b), with particular emphasis on the MarennesOléron Bay (Allard et al., 2010; Billeaud et al., 2005; Poirier et al., 2011). Inland, Holocene sediment infilling of the coastal marshes has been described from sedimentary cores, with a focus on the record of relative sea-level changes in the Poitevin Marsh (Clavé et al., 2001; Gruet and Sauriau, 1994; Sauriau and Gruet, 1988; Visset, 1987; Visset et al., 1990). A large array of boreholes has been retrieved in the marshes for geotechnical or hydrological studies, and provide additional descriptions of the marsh sediments (Carbonel et al., 1998; Decker et al., 2001; Weber et al., 2004b).

At the millennial scale, sediment infilling of the incised valleys was dominantly coarse-grained (Chaumillon and Weber, 2006). Stratigraphy was primarily controlled by rapid sea-level rise during the early Holocene (ca. $9 \mathrm{~mm} \mathrm{yr}^{-1}$; Lambeck, 1997; Stéphan and Goslin, 2014), which is similar to other sediment-starved incised valleys of the French Atlantic coasts (Chaumillon et al., 2008, 2010). Coarse-grained sediment infilling of the Pertuis Charentais is capped by a silt drape (ca. $820 \mathrm{~km}^{2}$ large, 1 to $1.5 \mathrm{~m}$ thick on average) that lies unconformably on older sand deposits (Billeaud et al., 2005; Chaumillon et al., 2004) and formed since about the 18th century (Poirier et al., 2011). Fine-grained sediment supply and trapping increased as a result of deforestation on catchments (Poirier et al., 2011), coastal marsh reclamation (Allard et al., 2008) and oyster farming (Bertin and Chaumillon, 2006).

\subsection{Sediment sources}

Sources of fine-grained sediments in the Pertuis Charentais include (1) coastal rivers flowing directly into the area, the largest being the Charente river (Fig. 1B), (2) the Gironde estuary that is located 35 km southwards (Dabrin et al., 2014; Parra et al., 1998), (3) Mesozoic marls and limestones outcropping along the coast, and (4) coastal marsh clay minerals (Parra et al., 1998).

By contrast, sources of coarse-grained sediments are poorly known. Mineralogical composition of sandy sediments in the Pertuis Charentais is markedly different from that of nearby Cenomanian sandstones or remnant Pleistocene fluvial terraces (Barusseau, 1967). This indicates the importance of hydrodynamical sorting of particles since the beginning of the Holocene marine transgression, and also suggests that much of the coarse-grained sediments in the area are not derived from ancient continental outcrops. Volumes of coarsegrained sediment infilling the Pertuis Breton are larger than those infilling the Pertuis d'Antioche. Given that both incised valleys are subjected to similar tide and wave regimes, and are connected to similarly-sized rivers, Chaumillon and Weber (2006) have concluded that the northern Pertuis Breton acted as a trap for marine sediments derived from the southward-oriented littoral drift. From these observations (Barusseau, 1967; Chaumillon and Weber, 2006), it 
appears that coarse-grained particles in the study area are therefore predominantly of marine, not continental, origin.

\section{Materials and methods}

The study relies on a compilation of both existing and new ${ }^{14} \mathrm{C}$ ages determined on marine mollusc shells retrieved from coarsegrained sediment bodies of the Pertuis Charentais. Three study areas were defined (Fig. 1B), including from north to south, (1) the inner Pertuis Breton and western Poitevin marsh, (2) the Rochefort marsh, and (3) the Marennes-Oléron bay and Brouage marsh, which make up a smaller system at the transition between the Charente and Seudre incised valleys (Allard et al., 2010).

\section{1. ${ }^{14} \mathrm{C}$ data compilation}

\subsubsection{Existing data}

Existing ${ }^{14} \mathrm{C}$ ages were published in regional monographs (Gabet, 1981; Regrain, 1980), in radiocarbon laboratory reports (Delibrias et al., 1974, 1982) and in peer-reviewed articles (Allard et al., 2010; Chaumillon et al., 2004; Chaumillon and Weber, 2006; Poirier et al., 2011).
Works carried out during the 1970's and 1980's provided mostly qualitative information about the stratigraphical context in which ${ }^{14} \mathrm{C}$ samples were retrieved, but descriptions were sufficiently detailed to ensure the provenance of these samples. ${ }^{14} \mathrm{C}$ measurements involved the scintillation method that yielded standard errors typically ranging between 90 and 100 years.

Works carried out since the 2000's involved extensive geophysical surveys of the Pertuis Charentais combined with abundant sedimentological and geochronological data, providing a precise control on the stratigraphic position of ${ }^{14} \mathrm{C}$ samples. Measurements involved the AMS method that yielded standard errors not greater than 30 years.

\subsubsection{New data}

The ${ }^{14} \mathrm{C}$ database was completed with new ages obtained on four sedimentary cores retrieved in 2013 with a vibro-corer in the Arçay sand spit (study area 1; Fig. 2A). Cores were positioned along Ground Penetrating Radar (GPR) profiles. GPR survey of the spit (40 km of profiles) was carried out with a GSSI SIR-3000 acquisition unit, equipped with a $400 \mathrm{MHz}$ antenna and a GPS (Tessier et al., 2013). Post-acquisition processing included enhancement of

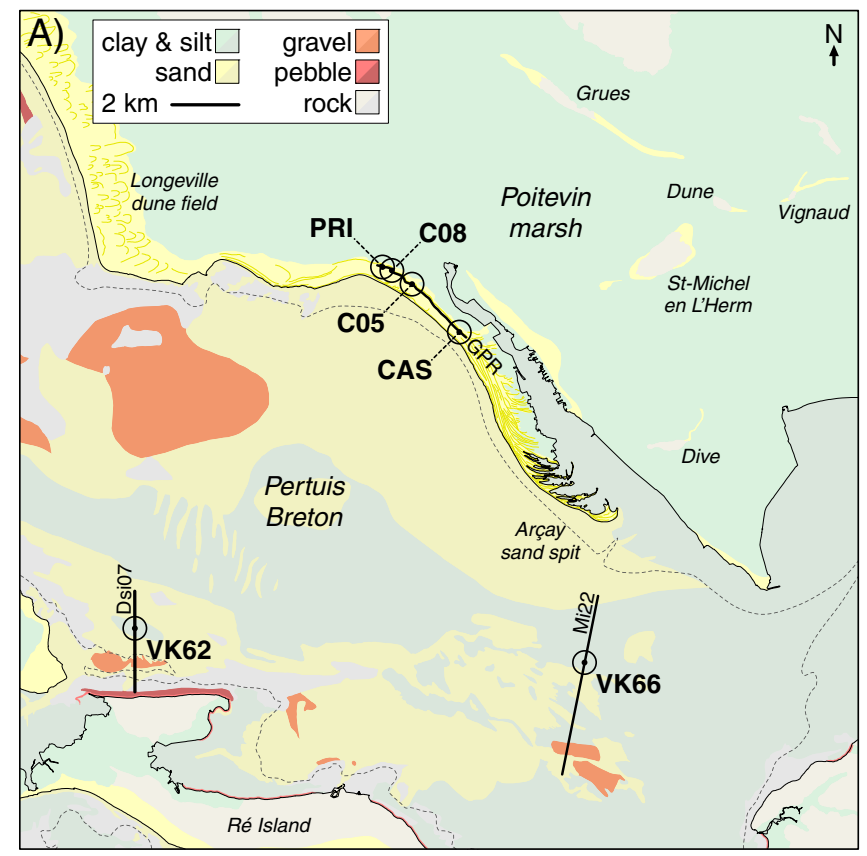

\section{B) Eastern Pertuis Breton}
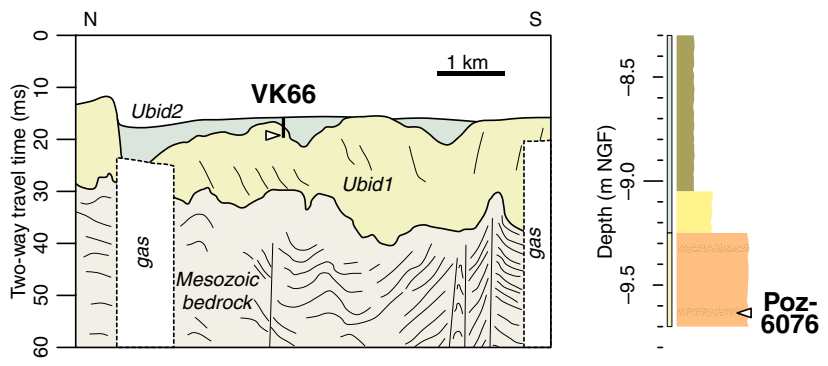

\section{C) Western Pertuis Breton}
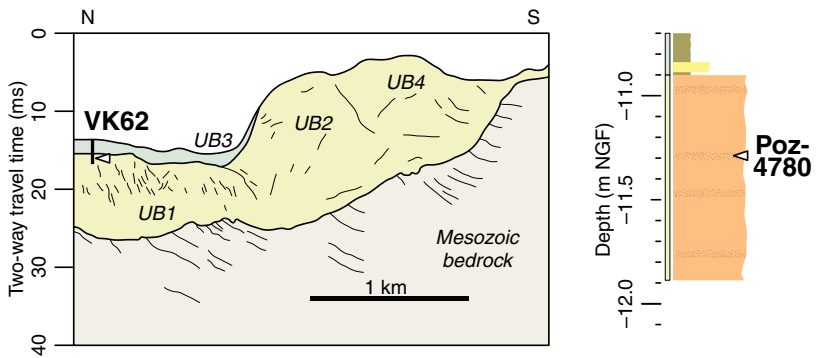

D) Arçay sand spit
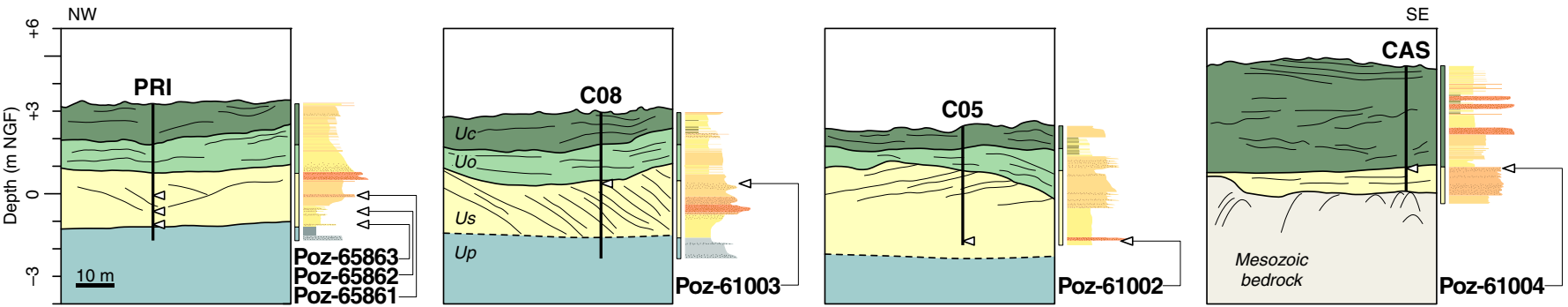

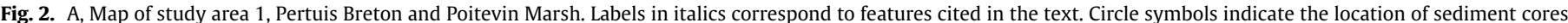

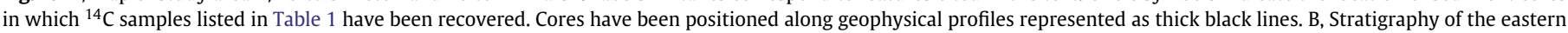

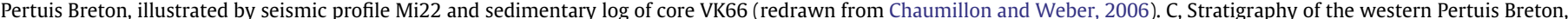

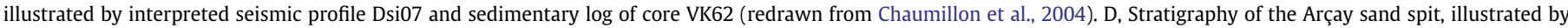

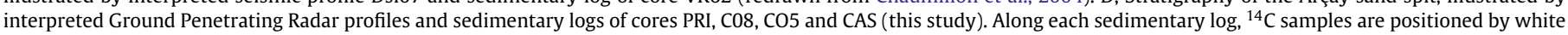
arrows labelled with corresponding laboratory codes. 


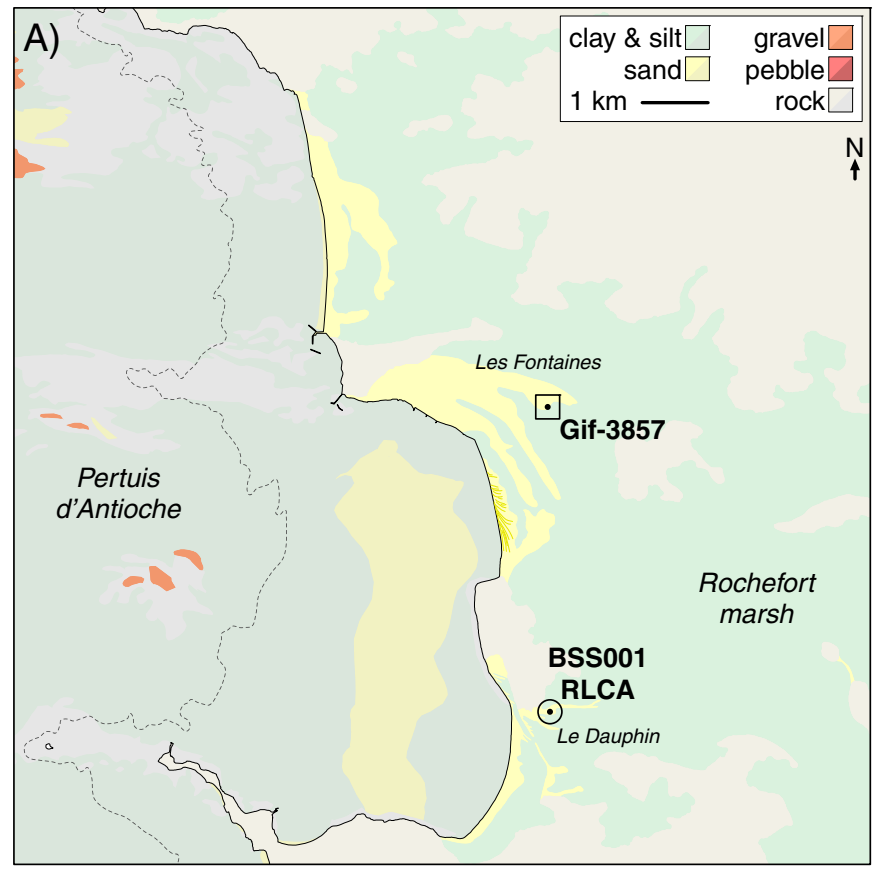

B) Rochefort marsh (Le Dauphin)

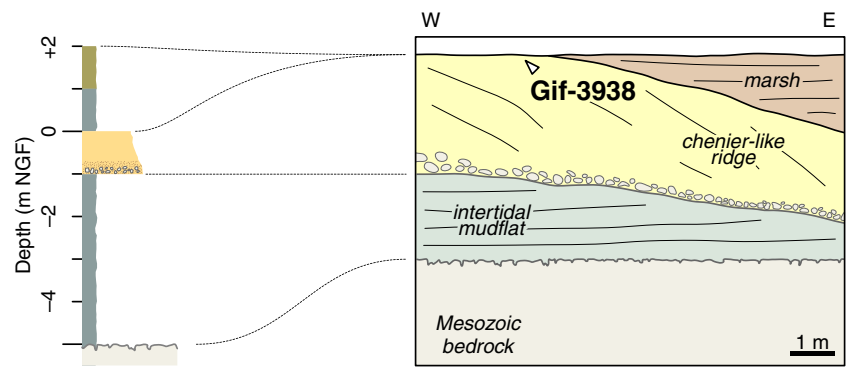

Fig. 3. A, Map of study area 2, Pertuis d'Antioche and Rochefort Marsh. Labels and symbols as in Fig. 2. Square symbol indicates the location of a ${ }^{14} \mathrm{C}$ sample for which a detailed description of the stratigraphical context is not available. B, Stratigraphy of Le Dauphin chenier-like ridge, interpreted from Regrain (1980) photograph description of a trench dug $450 \mathrm{~m}$ eastwards of sediment core BSS001RLCA. Dashed lines correlate sediment facies recognised in the trench and the core. ${ }^{14} \mathrm{C}$ sample Gif-3938 is positioned on the interpreted stratigraphic section with a labelled white arrow.

signal-to-noise ratio with a Karhunen-Loève filter (Zhao et al., 2005), time-to-depth conversion based on a variable velocity model (Allroggen et al., 2015), and topographic migration (Dujardin and Bano, 2013).

Sediment facies in the cores were visually described, and marine mollusc shells were sampled for ${ }^{14} \mathrm{C}$ age determination (AMS method; Poznań Radiocarbon Laboratory, Poland). In order to prevent dating of reworked material, only fully preserved remains, belonging to species ecologically compatible with the depositional environment were chosen. When applicable, thin-shelled infaunal bivalves were preferred, because they are indicative of a short postmortem residence at the water-sediment interface, and are thus expected to record more accurately the true timing of sediment deposition (Poirier et al., 2010). These selection criteria were also followed for ${ }^{14} \mathrm{C}$ samples reported by Allard et al. (2010) and Poirier et al. (2011), but it is unclear whether they were followed as well in the other works used to build the database.

\section{2. ${ }^{14} \mathrm{C}$ data processing}

Processing of the ${ }^{14} \mathrm{C}$ database (existing and new ages) was performed with Bchron package implemented in statistical analysis software R (Haslett and Parnell, 2008; Parnell et al., 2008). First, ${ }^{14} \mathrm{C}$ ages were calibrated against Marine13 reference curve (Reimer et al., 2013). The regional reservoir offset value $\Delta R$, which is here $-28 \pm$ 23 , is the inverse-error weighted average of 4 measurements carried out on mollusc shells of the Pertuis Charentais $(-36 \pm 40,-34 \pm 60$, $-32 \pm 39,+7 \pm 60$; Tisnérat-Laborde et al., 2010).

Function BchronDensity was then applied to the whole ${ }^{14} \mathrm{C}$ database, in order to combine the calibrated age distributions into a single, average age distribution. Instead of summing age probabilities, BchronDensity fits a mixture of a user-specified number $G$ of normal distributions (here $G=64$ ). The function relies on a stochastic algorithm (Markov Chain Monte Carlo) that produces slightly different results at each run. BchronDensity was therefore iterated 1000 times to improve reproducibility, and output was finally averaged.

\section{Results}

\subsection{Origin of samples}

Before describing the output of the BchronDensity function, this preliminary section provides a description of the geographical and stratigraphical context in which both existing and new ${ }^{14} \mathrm{C}$ samples have been retrieved from coarse-grained sediment bodies of the Pertuis Charentais. Although this section partly deals with published material, it is intended to serve as a guide to the description of ${ }^{14} \mathrm{C}$ results. Inland, these sediment bodies consist of thin, bedrock-attached chenier-like ridges that mark the position of former coastlines. They are depicted on fine-scale geological maps of the area (Bourgueil et al., 1976a,b, 1972; Hantzpergue, 1988; Platel et al., 1976; Verger et al., 1975). Local toponyms in the Poitevin Marsh ("Dune") and elsewhere in the area ("La Sablière", "La Gravelle") are consistent with the presence of sand or gravel-rich subsurface deposits that contrast with dominant clayey silt sediment infilling of the marshes. Within the Pertuis Charentais, Holocene sediments are buried under the large silt drape deposited since the 18th century. Coarse-grained sediment bodies outcrop in hydrodynamically active areas, where the silt drape is absent (Figs. 2A, 3A, 4A).

\subsubsection{Study area 1: Pertuis Breton and Poitevin marsh}

The sediment infilling of the Pertuis Breton is predominantly composed of marine sands and gravels, derived from the southwardoriented littoral drift. Subtidal sand outcrops (Fig. 2A) correspond to the top of back-stepping progradational wedges deposited in the area in response to Holocene sea-level rise (Weber et al., 2004a). In the eastern Pertuis Breton (Fig. 2B), ${ }^{14} \mathrm{C}$ sample Poz-6076 was recovered from core VK66 at a depth of $-9.60 \mathrm{~m} \mathrm{NGF}$, in order to determine the age of the sand wedge Ubid1 (Chaumillon and Weber, 2006). In the western Pertuis Breton (Fig. $2 \mathrm{C}$ ), ${ }^{14} \mathrm{C}$ sample Poz-4780 was recovered from core VK62 at a depth of $-11.30 \mathrm{~m} \mathrm{NGF}$, in order to determine the age of the sand wedge UB1 (Chaumillon et al., 2004).

New ${ }^{14} \mathrm{C}$ samples were recovered from the Arçay sand spit, which is composed of four stratigraphical units (Fig. 2D), described from base to top in the following. Unit Up has a transparent to lowamplitude horizontal radar facies correlated with blue-grey silty sands, interpreted as the spit platform (in the meaning of Allard et al., 2008). Unit Us displays high-amplitude, high-angle reflectors dipping southeastwards, in the direction of spit progradation. Us is composed of orange medium sands intercalated with discrete, centimetre-thick coarse shelly sand layers. It is interpreted as the main spit unit. Above, units Uo and Uc have medium amplitude, sub-horizontal or channelised reflectors. Uo consists of homogeneous fine sands containing abundant millimetre-thick laminations of dark heavy minerals, while such laminations disappear in Uc. Uo is interpreted as an exposed, upper beach environment, while Uc 
corresponds to a closed back-barrier tidal lagoon that formed along the northwestern Arçay sand spit, in response to human interventions during the 1970's (Poirier et al., 2017). ${ }^{14} \mathrm{C}$ sample Poz-61004 was recovered from core CAS at a depth of $+0.92 \mathrm{~m} \mathrm{NGF}$, in order to determine the age of the spit platform unit Up. Five other ${ }^{14} \mathrm{C}$ samples were retrieved from spit unit Us, including Poz-65681, 65682 and 65683 in core PRI $(-0.05,-0.65,-1.15 \mathrm{~m}$ NGF respectively), Poz-61002 in core C08 $(+0.37 \mathrm{~m} \mathrm{NGF)}$ and Poz-61002 in core C05 $(-1.70 \mathrm{~m} \mathrm{NGF})$.

\subsubsection{Study area 2: Rochefort marsh}

Chenier-like ridges occurring at the seaward margin of the Rochefort marsh (Fig. 3A) were qualitatively described and sampled for ${ }^{14} \mathrm{C}$ age determination by Regrain (1980). Sample Gif-3857 was taken in Les Fontaines at an approximate depth of $0 \mathrm{~m}$ NGF, and sample Gif-3938 was taken in Le Dauphin at an approximate depth of $+1.8 \mathrm{~m} \mathrm{NGF}$.

Internal architecture of Le Dauphin marsh was illustrated in Regrain (1980) by a photograph of a trench dug in the marsh, which shows a sand body lying between about -1 and +2 m NGF above a former intertidal mudflat, and eventually topped by marsh sediments (Fig. 3B). The description is confirmed by the borehole BSS001RLCA (Anonymous, 1997), which was drilled 450 m westward of the trench. Grey sands and gravels (3-4 mm) with abundant shell debris were observed between 0 and $-1 \mathrm{~m}$ NGF, hence confirming the probable presence of extensive chenier-like ridges in this area, as depicted on the local geological map (Bourgueil et al., 1972).

\subsubsection{Study area 3: Marennes-Oléron bay and surrounding marshes}

Similar subsurface coarse-grained deposits were identified and sampled for ${ }^{14} \mathrm{C}$ age determination in the Charente estuary and Brouage marsh (Fig. 4A) by Regrain (1980). They include the Soumard (Gif-4497, +3.6 m NGF) and Lupin (Gif-4498, +2.4 m NGF) chenierlike ridges along the Charente estuary, the Quadore (Gif-3856, +2.8 $\mathrm{m}$ NGF) and Nancras (MC-2158, +0.9 m NGF) chenier-like ridges, and a deep subtidal sand body lying directly over the bedrock in Brouage (Gif-3757, -20 m NGF; Gif-3758, -23 m NGF). To the west, Gabet (1981) described a large set of chenier-like ridges in the Salines marsh (Oléron Island, Fig. 4A). ${ }^{14} \mathrm{C}$ ages listed in a radiocarbon laboratory report (Delibrias et al., 1982) include Gif-3382 (+2 m NGF), Gif-4393 (+1.5 m NGF) and Gif-4395 (+2.5 m NGF).

The Holocene sediment infilling of the Marennes-Oléron bay has been extensively studied with very high resolution seismic profiles and ${ }^{14} \mathrm{C}$-dated sedimentary cores. To the west (Fig. 4B), three short sister cores penetrating into the top of a large progradational sand wedge recovered three ${ }^{14} \mathrm{C}$ ages (Poz-26302 in VC34, -7.1 m NGF; Poz-26303 in VC35, -6.5 m NGF; Poz-26304 in VC33, -8.7 m NGF), used for age determination of seismic unit UT3 (Allard et al., 2010; Billeaud et al., 2005). To the east (Fig. 4C), core UC01 provided a continuous record of sedimentation from units UT3 to UT4.2 (Poirier et al., 2011). Samples Poz-31120 ( -5.30 m NGF) and Poz-31121 ( $-4.15 \mathrm{~m}$ NGF) were recovered from sandy unit UT3 to confirm age determination of its western counterpart.

\subsection{Definition of coarse-grained sedimentation pulses (CSPS)}

The compiled database includes a total of twenty-four ${ }^{14} \mathrm{C}$ ages retrieved from coarse-grained sediment bodies of the Pertuis Charentais (Table 1). Two main age populations are recognised, ranging from $700 \pm 90$ (Gif-4395) to $1640 \pm 30$ uncal. yr B.P. (Poz-61004), and from $2650 \pm 100$ (Gif-4497) to $2880 \pm 100$ uncal. yr B.P. (Gif3382). Similar ${ }^{14} \mathrm{C}$ ages are found in much different geographical and stratigraphical contexts. For instance, samples Gif-4395 and Poz61002 were recovered from a chenier-like ridge in the Salines marsh (Fig. 4A) and from the Arçay sand spit unit Us (Fig. 2D) respectively, but both yielded equivalent ages of $700 \pm 90$ and $730 \pm 30$ uncal. yr B.P.

The 24 calibrated ${ }^{14} \mathrm{C}$ ages (Fig. 5A) were supplied to the $B$ chronDensity function. Averaged output is a complex, multimodal age distribution (Fig. 5B) with 7 well-defined peaks of age probability centered on two distinct periods, from about 300 to 1400 cal. yr B.P. and from about 2300 to 2900 cal. yr B.P. We define each age peak as a coarse-grained sedimentation pulse (CSP), assuming that formation of independent, disconnected coarse-grained deposits reflects a synchronous event occurring in the whole Pertuis Charentais area. The multimodal age distribution was decomposed into a subset of individual normal distributions in order to determine the age ranges of each CSP. Decomposition was carried out by a density estimation algorithm implemented in R package mclust (Fraley and Raferty, 2002). CSPs are labelled $A$ to $G$, from the youngest to the oldest, and have ages of $445 \pm 50,649 \pm 64,797 \pm 47,968 \pm 62,1240 \pm 53,2422$ \pm 54 and $2646 \pm 62$ cal. yr B.P., respectively (Table 2 ).

\subsection{Recognition of CSPs along European coasts}

An additional dataset of $39{ }^{14} \mathrm{C}$ and OSL ages obtained on waveinfluenced environments of western Europe was built (Table 3), in order to determine whether CSPs identified in the Pertuis Charentais reflect a local or regional signal. Dated deposits include spits, beaches (including unconsolidated sands and beachrocks) and ridges (including cheniers and plains) from the exposed coasts of Germany, United Kingdom, France, Spain and Portugal (Fig. 6A). When publications already reported calibrated age ranges, they were recalculated to ensure a consistent processing of the dataset, using an up-to-date calibration curve (Marine13) and $\Delta \mathrm{R}$ values determined from the on-line "Marine Reservoir Correction" database (Reimer and Reimer, 2006). The BchronDensity function was not applied to this dataset, which is more heterogeneous in terms of sample provenance.

For latitudes between $55^{\circ}$ (Sylt, Germany) and $43^{\circ} \mathrm{N}$ (Punta Gallín, Spain), two main age populations are distinguished. The most recent one ranges from about 300 to $1300 \mathrm{cal}$. yr B.P., matching the $2 \sigma$ boundaries of CSPs A to E, and the oldest one ranges from about 2100 to 3100 cal. yr B.P., matching the $2 \sigma$ boundaries of CSPs F and G. ${ }^{14} \mathrm{C}$ ages obtained on spits and beachrocks of the Cadix Gulf (southern Spain and Portugal), around $37^{\circ} \mathrm{N}$, range from about 400 to $3000 \mathrm{cal}$. yr B.P. and do not match this overall dichotomy (Fig. 6B). Maximum probability age of some samples falls precisely within, or very close to, the CSP age ranges (Fig. 6B; Tables 2, 3). This is the case e.g. for ${ }^{14}$ C sample KIA-31638 from Sylt spit, Germany (562-261 cal. yr B.P., equivalent to CSP A ), for OSL samples of the Dungeness beach ridge plain, United Kingdom (1053-856 cal. yr B.P., equivalent to CSP D), or for ${ }^{14} \mathrm{C}$ sample CNA-1053 from Punta Gallín beach, Spain (907-675 cal. yr B.P., equivalent to CSP C).

Other samples, such as CNA-1052 (643-468 cal. yr B.P.) from Punta Gallín beach, fall in between two CSPs (here A and B), or have large calibration ranges which make the connection with a CSP more questionable (e.g. UQ-2058 in Cordon de Richard chenier, France; 3091-2465 cal. yr B.P., possibly equivalent to CSP G). The lowest agreement is found for ${ }^{14} \mathrm{C}$ ages of the Cadix Gulf, for which only 5 samples out of 19 can be associated with CSPs. Poor agreement also exists for ${ }^{14} \mathrm{C}$ ages obtained on beachrocks (Gif-1100 in Plage de la Torche, France; IRPA-20056 and Beta-185788 in Armação de Pêra, Portugal), which are out of the CSPs $2 \sigma$ age ranges (Fig. 6B).

\section{Discussion}

The basic assumption of this study is that CSPs in the Pertuis Charentais reflect a regional shift towards more energetic marine conditions. While the contribution of relative sea-level changes to the occurrence of CSPs cannot be excluded, it is probably minor in the context of the steady, slow sea-level rise recorded along 


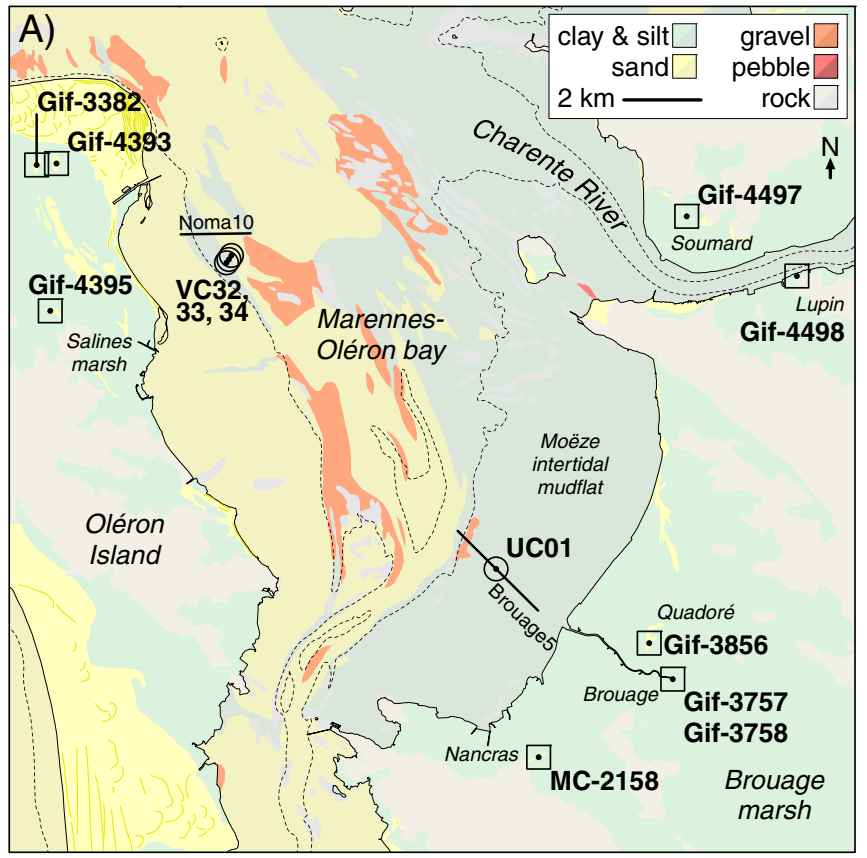

\section{B) Western Marennes-Oléron bay}
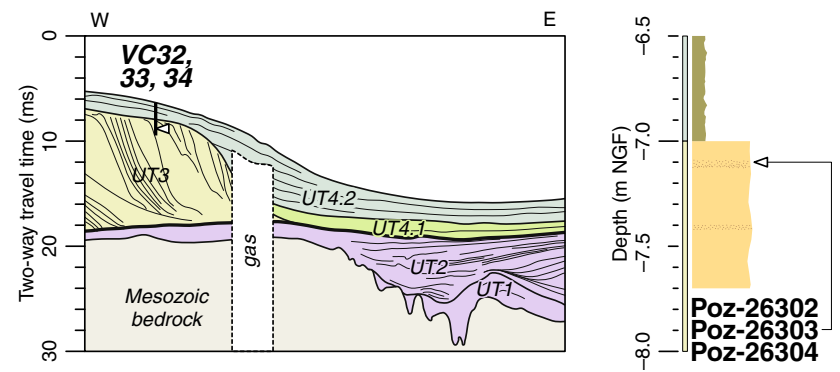

C) Eastern Marennes-Oléron bay

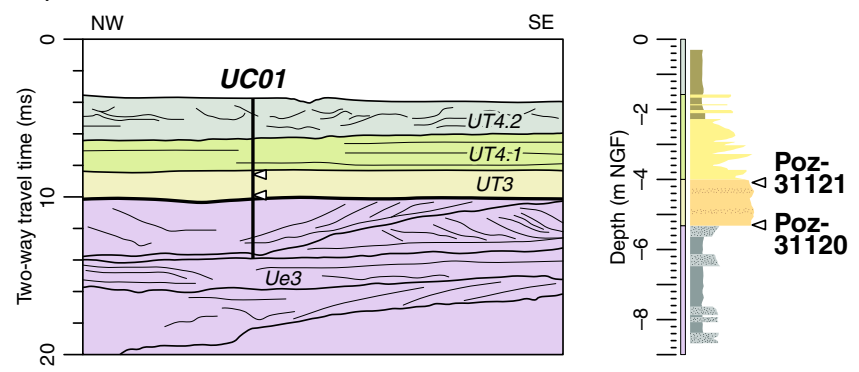

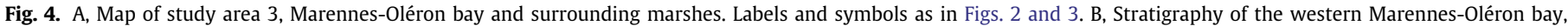

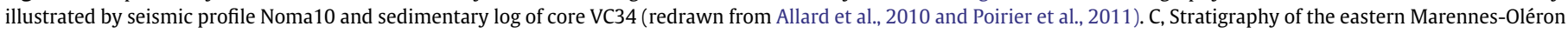
bay, illustrated by seismic profile Brouage5 and sedimentary log of core UC01 (redrawn from Poirier et al., 2011).

French Atlantic coasts during the late Holocene (Lambeck, 1997; Stéphan and Goslin, 2014). In this section, the external climate drivers involved in the occurrence of CSPs are discussed, by comparing CSP age ranges with time series of the North Atlantic Ocean climate since 3500 cal. yr B.P. (Fig. 7).

\subsection{Impact of storminess}

A key finding of this study is that CSPs do not coincide with the two last phases of increased North Atlantic storminess previously identified in various studies from about 2000 to 1200 cal. yr B.P. and from about 600 to 150 cal. yr B.P. (Fig. 5B; HSAP, "high storm activity period" in Sabatier et al., 2012; HSP, "Holocene Storm Period" in Sorrel et al., 2012; van Vliet-Lanoë et al., 2014; SP, "storm periods" in Degeai et al., 2015; Costas et al., 2016 and references therein).

Inversely, CSPs coincide with decreasing or minima values in the 1450-yr wavelet reconstruction of the IRD time series (Fig. 7C; Bond et al., 2001), i.e. during periods of decreased North Atlantic storminess (Sorrel et al., 2012). The same observation applies for a clay mineralogy record of lagoonal sediments in the northwestern Mediterranean Sea (Sabatier et al., 2012), for which CSPs coincide with above-average ( $>1.2$ ) values in the smectite/(illite + chlorite) ratio, interpreted by the authors as a proxy of reduced storm activity (Fig. 7D). Wavelet reconstruction of this clay mineralogy time

Table 1

${ }^{14} \mathrm{C}$ database (Pertuis Charentais).

\begin{tabular}{|c|c|c|c|c|c|c|c|}
\hline Lab reference & ${ }^{14} \mathrm{C}$ age (uncal. yr B.P.) & Study area & Toponym & Publication reference & Type & $2 \sigma$ range (cal. yr B.P.) & $1 \sigma$ range (cal. yr B.P.) \\
\hline Gif-4395 & $700 \pm 90$ & 3 & Arceau & Delibrias et al., 1982 & Chenier-like & $518-185$ & $452-289$ \\
\hline Poz-61002 & $730 \pm 30$ & 1 & Pointe d'Arçay & This study & Spit & $472-307$ & $453-358$ \\
\hline Poz-65861 & $750 \pm 30$ & 1 & Pointe d'Arçay & This study & Spit & $487-319$ & $473-386$ \\
\hline Poz-65862 & $755 \pm 30$ & 1 & Pointe d'Arçay & This study & Spit & $490-324$ & $477-394$ \\
\hline Poz-65863 & $850 \pm 30$ & 1 & Pointe d'Arçay & This study & Spit & $548-440$ & $521-473$ \\
\hline MC-2158 & $900 \pm 70$ & 3 & Le Grand Nancras & Regrain, 1980 & Chenier-like & $650-430$ & $601-487$ \\
\hline Poz-61003 & $975 \pm 30$ & 1 & Pointe d'Arçay & This study & Spit & $646-523$ & $621-551$ \\
\hline Poz-31121 & $1065 \pm 30$ & 3 & Moëze tidal flat & Poirier et al., 2011 & Subtidal (marine) & $721-590$ & $681-627$ \\
\hline Gif-3856 & $1150 \pm 90$ & 3 & Quadoré & Regrain, 1980 & Chenier-like & $910-590$ & $819-647$ \\
\hline Poz-26302 & $1165 \pm 30$ & 3 & Rade des Trousses & Allard et al., 2010 & Subtidal (marine) & $821-660$ & $765-687$ \\
\hline Gif-3938 & $1230 \pm 100$ & 2 & Le Dauphin & Regrain, 1980 & Chenier-like & $1012-630$ & $900-708$ \\
\hline Poz-26304 & $1235 \pm 30$ & 3 & Rade des Trousses & Allard et al., 2010 & Subtidal (marine) & $899-721$ & $865-762$ \\
\hline Poz-26303 & $1245 \pm 30$ & 3 & Rade des Trousses & Allard et al., 2010 & Subtidal (marine) & $904-729$ & $875-776$ \\
\hline Gif-3857 & $1280 \pm 90$ & 2 & Les Fontaines & Regrain, 1980 & Chenier-like & $1039-672$ & $934-748$ \\
\hline Gif-4498 & $1390 \pm 90$ & 3 & Lupin & Regrain, 1980 & Chenier-like & $1174-763$ & $1081-872$ \\
\hline Poz-31120 & $1420 \pm 30$ & 3 & Moëze tidal flat & Poirier et al., 2011 & Subtidal (marine) & 1085-912 & $1037-949$ \\
\hline Poz-61004 & $1640 \pm 30$ & 1 & Pointe d'Arçay & This study & Spit & 1295-1155 & $1269-1200$ \\
\hline Gif-3758 & $1790 \pm 100$ & 3 & Brouage marsh & Delibrias et al., 1982 & Subtidal (marsh) & 1594-1172 & $1480-1275$ \\
\hline Gif-4497 & $2650 \pm 100$ & 3 & Soumard & Regrain, 1980 & Chenier-like & $2682-2137$ & $2567-2267$ \\
\hline Poz-4780 & $2695 \pm 30$ & 1 & Pertuis Breton & Chaumillon et al., 2004 & Subtidal (marine) & $2575-2324$ & 2469-2349 \\
\hline Gif-4393 & $2710 \pm 100$ & 3 & La Moulinade & Delibrias et al., 1982 & Chenier-like & $2723-2241$ & $2608-2335$ \\
\hline Gif-3757 & $2770 \pm 100$ & 3 & Brouage marsh & Delibrias et al., 1982 & Subtidal (marsh) & $2751-2301$ & $2682-2420$ \\
\hline Poz-6076 & $2815 \pm 30$ & 1 & Pertuis Breton & Chaumillon and Weber, 2006 & Subtidal (marine) & $2714-2480$ & $2692-2561$ \\
\hline Gif-3382 & $2880 \pm 100$ & 3 & La Moulinade & Delibrias et al., 1982 & Chenier-like & $2878-2359$ & $2776-2512$ \\
\hline
\end{tabular}




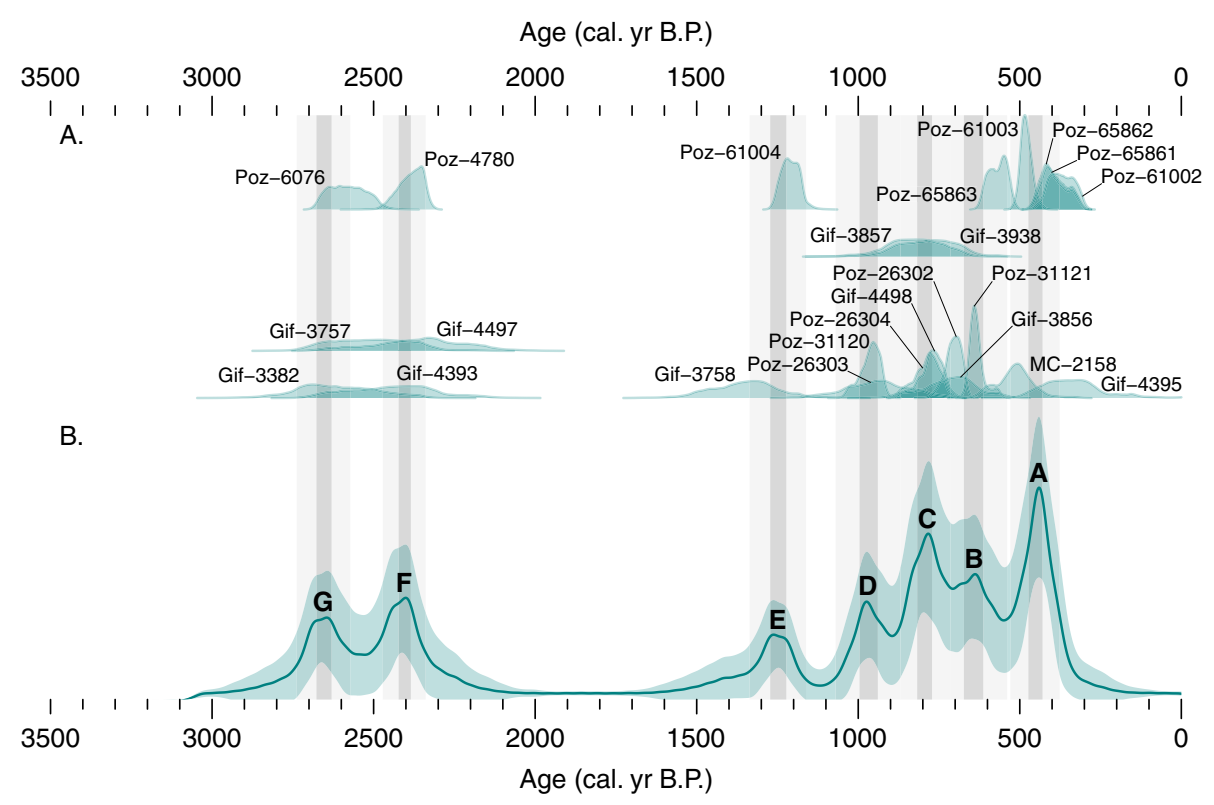

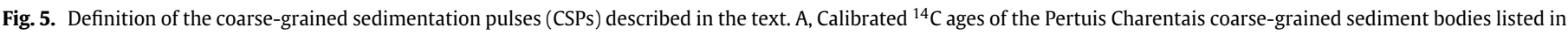

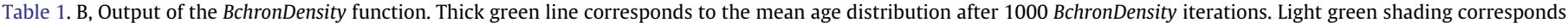
to the $2 \sigma$ enveloppe.

series for the 1450-yr cycle is in phase with that obtained for the IRD time series (Fig. 7C). The occurrence of CSPs is therefore likely conditioned by a decrease in the frequency and/or intensity of North Atlantic storms. Such conditions are believed to allow the deposition and long-term preservation of coarse-grained sediments in the Pertuis Charentais. It is likely that coastal barriers in the study area repeatedly switched between phases of destruction during HSPs (ca. 3500 to 2700,2000 to 1200 , and 600 to $150 \mathrm{cal}$. yr B.P.) and resilience between HSPs (2700 to 2000 and 1200 to 600 cal. yr B.P.)

\subsection{Impact of wave climate}

According to the present-day wave climate studies described above (Martínez-Asensio et al., 2016; Poirier et al., 2017), waveinduced sediment transport in the study area increases with positive NAO and negative EA/WR conditions. Several reconstructions of lowto high-frequency changes in the NAO index are available for the late Holocene to historical periods, with differences in temporal coverage and resolution (Fig. 7E; Baker et al., 2015; Olsen et al., 2012; Ortega et al., 2015; Proctor et al., 2000; Trouet et al., 2009). The EA/WR atmospheric circulation pattern has received less attention, with a focus mostly on its impact on temperature and precipitation in western Europe and in the Mediterranean region (Ionita, 2014; Krichak and Alpert, 2005; Lim, 2015, and references therein). To our knowledge, no reconstruction of the late Holocene EA/WR variability exists yet. Given that a positive correlation between EA/WR and

Table 2

Chronological boundaries of coarse-grained sedimentation pulses (CSPs).

\begin{tabular}{llll}
\hline CSP & $\begin{array}{l}2 \sigma \text { range } \\
\text { (cal. yr B.P.) }\end{array}$ & $\begin{array}{l}1 \sigma \text { range } \\
(\text { cal. yr B.P.) }\end{array}$ & $\begin{array}{l}\text { Normal distribution } \\
\text { (cal. yr B.P.) }\end{array}$ \\
\hline A & $526-362$ & $466-420$ & $445 \pm 50$ \\
B & $753-543$ & $676-616$ & $649 \pm 64$ \\
C & $874-719$ & $817-773$ & $797 \pm 47$ \\
D & $1070-866$ & $995-937$ & $968 \pm 62$ \\
E & $1328-1152$ & $1263-1213$ & $1240 \pm 53$ \\
F & $2510-2333$ & $2445-2395$ & $2422 \pm 54$ \\
G & $2748-2544$ & $2673-2615$ & $2646 \pm 62$ \\
\hline
\end{tabular}

precipitation rates is observed across Asia (Barnston and Livezey, 1987), with negative EA/WR conditions inducing a drier climate, we use a record of late Holocene summer (JJAS) precipitation from lake Ngamring Tso, southern Tibet (Conroy et al., 2017) as an indirect proxy of the long-term EA/WR variability (Fig. 7F).

CSPs A to E (i.e. 450 to 1250 cal. yr B.P.) coincide with dominantly positive NAO conditions prevailing from about 500 to 1900 cal. yr B.P. (Fig. 7E; Baker et al., 2015; Olsen et al., 2012), and with dominantly negative EA/WR conditions from about 400 to $1700 \mathrm{cal}$. yr B.P. (Fig. 7F; Conroy et al., 2017). Although the $1 \sigma$ age ranges of CSPs A to E coincide with minor, slightly positive EA/WR peaks occurring within the overall negative trend (Fig. 7F), they also closely match positive NAO peaks (Ortega et al., 2015; Trouet et al., 2009), or periods of decreasing NAO after these peaks (Olsen et al., 2012), depending on the reconstructions (Fig. 7B). It is therefore very likely that CSPs A to $\mathrm{E}$ reflect periods of increased deposition of coarsegrained sediments in the Pertuis Charentais, induced by a more energetic wave climate. This interpretation partly applies for CSPs F and G (2400 and 2650 cal. yr B.P.), as they closely match the likely most negative EA/WR peaks reached since the last 3500 years, but also moderately to strongly negative NAO peaks (Fig. 7E,7F). Such climate conditions have no present-day analogue, and it is therefore difficult to determine to which extent they contributed to a more energetic wave climate as for CSPs A to E.

\subsection{Climate control on CSPs along European coasts}

Additional ${ }^{14} \mathrm{C}$ and OSL ages obtained on wave-influenced environments of western Europe (Fig. 6; Table 3) provide some clues about the broader geographical and hydrodynamical context in which CSPs have been recorded. Most ${ }^{14} \mathrm{C}$ and OSL ages from northern Europe (above $43^{\circ} \mathrm{N}$ ) could be related to CSPs identified in the Pertuis Charentais database with fair (e.g. UQ-2058) to excellent agreement (e.g. SacA-23973; Table 1). Conversely, agreement is poor or non-existent for ${ }^{14} \mathrm{C}$ ages from southern Spain and Portugal (around $37^{\circ} \mathrm{N}$ ). Spit growth in this area may not only depend on wave climate variability, but also indirectly on progradation of 
Table 3

\begin{tabular}{|c|c|c|c|c|c|c|c|c|}
\hline Reference & Lab code & Age (uncal. yr B.P.) & Method & Location & Latitude & Depositional environment & $2 \sigma$ range (cal. yr B.P.) & CSP \\
\hline Lindhorst et al., 2010 & KIA-31638 & $775 \pm 25$ & ${ }^{14} \mathrm{C}$ & Sylt, Germany ${ }^{\mathrm{a}}$ & $54^{\circ} 54,7^{\prime} \mathrm{N}$ & Spit & $562-261$ & A \\
\hline Lindhorst et al., 2010 & KIA-31639 & $1350 \pm 30$ & ${ }^{14} \mathrm{C}$ & Sylt, Germany & $54^{\circ} 54,7^{\prime} \mathrm{N}$ & Spit & $1121-725$ & D \\
\hline Roberts and Plater, 2007 & several $^{\mathrm{b}}$ & $1005 \pm 50$ & OSL & Dungeness, United Kingdom & $50^{\circ} 55,9^{\prime} \mathrm{N}$ & Ridge (plain) & $1053-856$ & $\mathrm{D}$ \\
\hline van Vliet-Lanoë et al., 2014 & SacA-23972 & $565 \pm 30$ & ${ }^{14} \mathrm{C}$ & Plage de la Torche, France ${ }^{c}$ & $47^{\circ} 50,3^{\prime} \mathrm{N}$ & Beachrock & $297-178$ & None \\
\hline Giot, 1998 & Gif-891 & $1100 \pm 90$ & ${ }^{14} \mathrm{C}$ & Plage de la Torche, France & $47^{\circ} 50,3^{\prime} \mathrm{N}$ & Beach (unconsolidated) & $876-548$ & B \\
\hline van Vliet-Lanoë et al., 2014 & SacA-23973 & $1390 \pm 30$ & ${ }^{14} \mathrm{C}$ & Plage de la Torche, France & $47^{\circ} 50,3^{\prime} \mathrm{N}$ & Beach (unconsolidated) & $1037-920$ & D \\
\hline van Vliet-Lanoë et al., 2014 & Poz-36728 & $1435 \pm 30$ & ${ }^{14} \mathrm{C}$ & Plage de la Torche, France & $47^{\circ} 50,3^{\prime} \mathrm{N}$ & Beach (unconsolidated) & $1088-948$ & D \\
\hline van Vliet-Lanoë et al., 2014 & Poz-37202 & $1460 \pm 30$ & ${ }^{14} \mathrm{C}$ & Plage de la Torche, France & $47^{\circ} 50,3^{\prime} \mathrm{N}$ & Beach (unconsolidated) & $1129-972$ & D \\
\hline van Vliet-Lanoë et al., 2014 & Poz-36729 & $1600 \pm 30$ & ${ }^{14} \mathrm{C}$ & Plage de la Torche, France & $47^{\circ} 50,3^{\prime} \mathrm{N}$ & Beach (unconsolidated) & $1262-1159$ & $\mathrm{E}$ \\
\hline van Vliet-Lanoë et al., 2014 & Poz-34212 & $1605 \pm 30$ & ${ }^{14} \mathrm{C}$ & Plage de la Torche, France & $47^{\circ} 50,3^{\prime} \mathrm{N}$ & Beachrock & $1264-1164$ & $\mathrm{E}$ \\
\hline van Vliet-Lanoë et al., 2014 & Poz-31327 & $1620 \pm 30$ & ${ }^{14} \mathrm{C}$ & Plage de la Torche, France & $47^{\circ} 50,3^{\prime} \mathrm{N}$ & Beach (unconsolidated) & $1271-1174$ & $\mathrm{E}$ \\
\hline Giot, 1981 & Gif-1100 & $2670 \pm 110$ & ${ }^{14} \mathrm{C}$ & Plage de la Torche, France & $47^{\circ} 50,3^{\prime} \mathrm{N}$ & Beachrock & $2701-2163$ & F and/or G \\
\hline Pontee et al., 1998 & n.a. ${ }^{\mathrm{d}}$ & $1421 \pm 162$ & ${ }^{14} \mathrm{C}$ & Cordon de Richard, France ${ }^{e}$ & $45^{\circ} 29,3^{\prime} \mathrm{N}$ & Ridge (chenier) & $1292-686$ & $\mathrm{D}$ \\
\hline Clavé, 2001 & UQ-1983 & $1600 \pm 135$ & ${ }^{14} \mathrm{C}$ & Cordon de Richard, France & $45^{\circ} 29,3^{\prime} \mathrm{N}$ & Ridge (chenier) & $1460-915$ & E \\
\hline Pontee et al., 1998 & n.a. & $2575 \pm 120$ & ${ }^{14} \mathrm{C}$ & Cordon de Richard, France & $45^{\circ} 29,3^{\prime} \mathrm{N}$ & Ridge (chenier) & $2647-2005$ & $\mathrm{~F}$ ? \\
\hline Clavé, 2001 & Beta-102696 & $2590 \pm 70$ & ${ }^{14} \mathrm{C}$ & Cordon de Richard, France & $45^{\circ} 29,3^{\prime} \mathrm{N}$ & Ridge (chenier) & $2493-2117$ & $\mathrm{~F}$ ? \\
\hline Clavé, 2001 & Beta-102695 & $2850 \pm 90$ & ${ }^{14} \mathrm{C}$ & Cordon de Richard, France & $45^{\circ} 29,3^{\prime} \mathrm{N}$ & Ridge (chenier) & 2819-2377 & G \\
\hline Clavé, 2001 & UQ-2058 & $2975 \pm 120$ & ${ }^{14} \mathrm{C}$ & Cordon de Richard, France & $45^{\circ} 29,3^{\prime} \mathrm{N}$ & Ridge (chenier) & $3091-2465$ & $\mathrm{G} ?$ \\
\hline Feal-Pérez et al., 2014 & CNA-1052 & $1048 \pm 35$ & ${ }^{14} \mathrm{C}$ & Punta Gallín, Spain ${ }^{f}$ & $43^{\circ} 33,4^{\prime} \mathrm{N}$ & Beach (unconsolidated) & $643-468$ & None \\
\hline Feal-Pérez et al., 2014 & CNA-1053 & $1347 \pm 36$ & ${ }^{14} \mathrm{C}$ & Punta Gallín, Spain & $43^{\circ} 33,4^{\prime} \mathrm{N}$ & Beach (unconsolidated) & $907-675$ & C \\
\hline Zazo et al., 1994 & R-2207 & $1440 \pm 50$ & ${ }^{14} \mathrm{C}$ & El Rompido, Spaing & $37^{\circ} 13,0^{\prime} \mathrm{N}$ & Spit & 933-549 & None \\
\hline Zazo et al., 1994 & $\mathrm{R}-2179$ & $1460 \pm 50$ & ${ }^{14} \mathrm{C}$ & El Rompido, Spain & $37^{\circ} 13,0^{\prime} \mathrm{N}$ & Spit & $953-560$ & None \\
\hline Zazo et al., 1994 & $\mathrm{R}-2180$ & $1875 \pm 50$ & ${ }^{14} \mathrm{C}$ & El Rompido, Spain & $37^{\circ} 13,0^{\prime} \mathrm{N}$ & Spit & 1369-941 & $\mathrm{E} ?$ \\
\hline Zazo et al., 1994 & $\mathrm{R}-2203$ & $2605 \pm 50$ & ${ }^{14} \mathrm{C}$ & El Rompido, Spain & $37^{\circ} 13,0^{\prime} \mathrm{N}$ & Spit & $2270-1732$ & None \\
\hline Moura et al., 2007 & IRPA-20056 & $710 \pm 20$ & ${ }^{14} \mathrm{C}$ & Armação de Pêra, Portugal & $37^{\circ} 05,9^{\prime} \mathrm{N}$ & Beachrock & $280-0$ & None \\
\hline Moura et al., 2007 & Beta-185788 & $2280 \pm 40$ & ${ }^{14} \mathrm{C}$ & Armação de Pêra, Portugal & $37^{\circ} 05,9^{\prime} \mathrm{N}$ & Beachrock & $1840-1351$ & None \\
\hline Zazo et al., 1994 & $\mathrm{R}-2204$ & $1490 \pm 50$ & ${ }^{14} \mathrm{C}$ & Doñana, Spain & $36^{\circ} 49,7^{\prime} \mathrm{N}$ & Spit & $986-594$ & $\mathrm{C}$ \\
\hline Zazo et al., 1994 & $\mathrm{R}-2187$ & $1790 \pm 50$ & ${ }^{14} \mathrm{C}$ & Doñana, Spain & $36^{\circ} 49,7^{\prime} \mathrm{N}$ & Spit & $1296-882$ & D \\
\hline Zazo et al., 1994 & $\mathrm{R}-2188$ & $1850 \pm 50$ & ${ }^{14} \mathrm{C}$ & Doñana, Spain & $36^{\circ} 49,7^{\prime} \mathrm{N}$ & Spit & $1340-924$ & None \\
\hline Zazo et al., 1994 & $\mathrm{R}-2185$ & $1860 \pm 50$ & ${ }^{14} \mathrm{C}$ & Doñana, Spain & $36^{\circ} 49,7^{\prime} \mathrm{N}$ & Spit & $1350-929$ & $\mathrm{E} ?$ \\
\hline Zazo et al., 1994 & $\mathrm{R}-2210$ & $2010 \pm 50$ & ${ }^{14} \mathrm{C}$ & Doñana, Spain & $36^{\circ} 49,7^{\prime} \mathrm{N}$ & Spit & $1535-1078$ & E \\
\hline Zazo et al., 1994 & $\mathrm{R}-2205$ & $2185 \pm 50$ & ${ }^{14} \mathrm{C}$ & Doñana, Spain & $36^{\circ} 49,7^{\prime} \mathrm{N}$ & Spit & $1729-1273$ & None \\
\hline Rodríguez-Polo et al., 2009 & AERO & $1190 \pm 80$ & ${ }^{14} \mathrm{C}$ & Valdelagrana, Spain & $36^{\circ} 32,2^{\prime} \mathrm{N}$ & Spit & $695-328$ & None \\
\hline Rodríguez-Polo et al., 2009 & ESCA & $1250 \pm 70$ & ${ }^{14} \mathrm{C}$ & Valdelagrana, Spain & $36^{\circ} 32,2^{\prime} \mathrm{N}$ & Spit & $773-417$ & None \\
\hline Rodríguez-Polo et al., 2009 & TORVC-4 & $1590 \pm 60$ & ${ }^{14} \mathrm{C}$ & Valdelagrana, Spain & $36^{\circ} 32,2^{\prime} \mathrm{N}$ & Spit & $1109-671$ & None \\
\hline Zazo et al., 1994 & $\mathrm{R}-2186$ & $2120 \pm 50$ & ${ }^{14} \mathrm{C}$ & Valdelagrana, Spain & $36^{\circ} 32,2^{\prime} \mathrm{N}$ & Spit & $1674-1226$ & None \\
\hline Zazo et al., 1994 & $\mathrm{R}-2181$ & $2270 \pm 50$ & ${ }^{14} \mathrm{C}$ & Valdelagrana, Spain & $36^{\circ} 32,2^{\prime} \mathrm{N}$ & Spit & $1826-1340$ & None \\
\hline Zazo et al., 1994 & $\mathrm{R}-2182$ & $2320 \pm 50$ & ${ }^{14} \mathrm{C}$ & Valdelagrana, Spain & $36^{\circ} 32,2^{\prime} \mathrm{N}$ & Spit & $1882-1386$ & None \\
\hline Zazo et al., 1994 & $\mathrm{R}-2208$ & $3145 \pm 50$ & ${ }^{14} \mathrm{C}$ & Valdelagrana, Spain & $36^{\circ} 32,2^{\prime} \mathrm{N}$ & Spit & $2864-2345$ & G \\
\hline
\end{tabular}

a $\Delta R=-23 \pm 92$; average of values Nos. 73,74 and 75 (see on-line "Marine Reservoir Correction" database for details; Reimer and Reimer, 2006).

b Average of samples $73 \mathrm{BH}-7 / 1 ; 73 \mathrm{BH}-9 / 1,2,3 ; 73 \mathrm{BH}-10 / 1,2,3$. OSL ages were reported in years before $2000 \mathrm{CE}$ and were therefore offset by 50 years for comparison with ${ }^{14} \mathrm{C}$ expressed in cal. yr B.P.

c $\Delta R=-40 \pm 23 ;$ value No. 1075 .

n.a., not applicable.

$\Delta R=-34 \pm 60$; value No. 1574

$\Delta \mathrm{R}=+101 \pm 65 ;$ average of values Nos. 132,1553 and 1554

g $\Delta R=+253 \pm 110$; average of values Nos. 133 to 144 and 146 

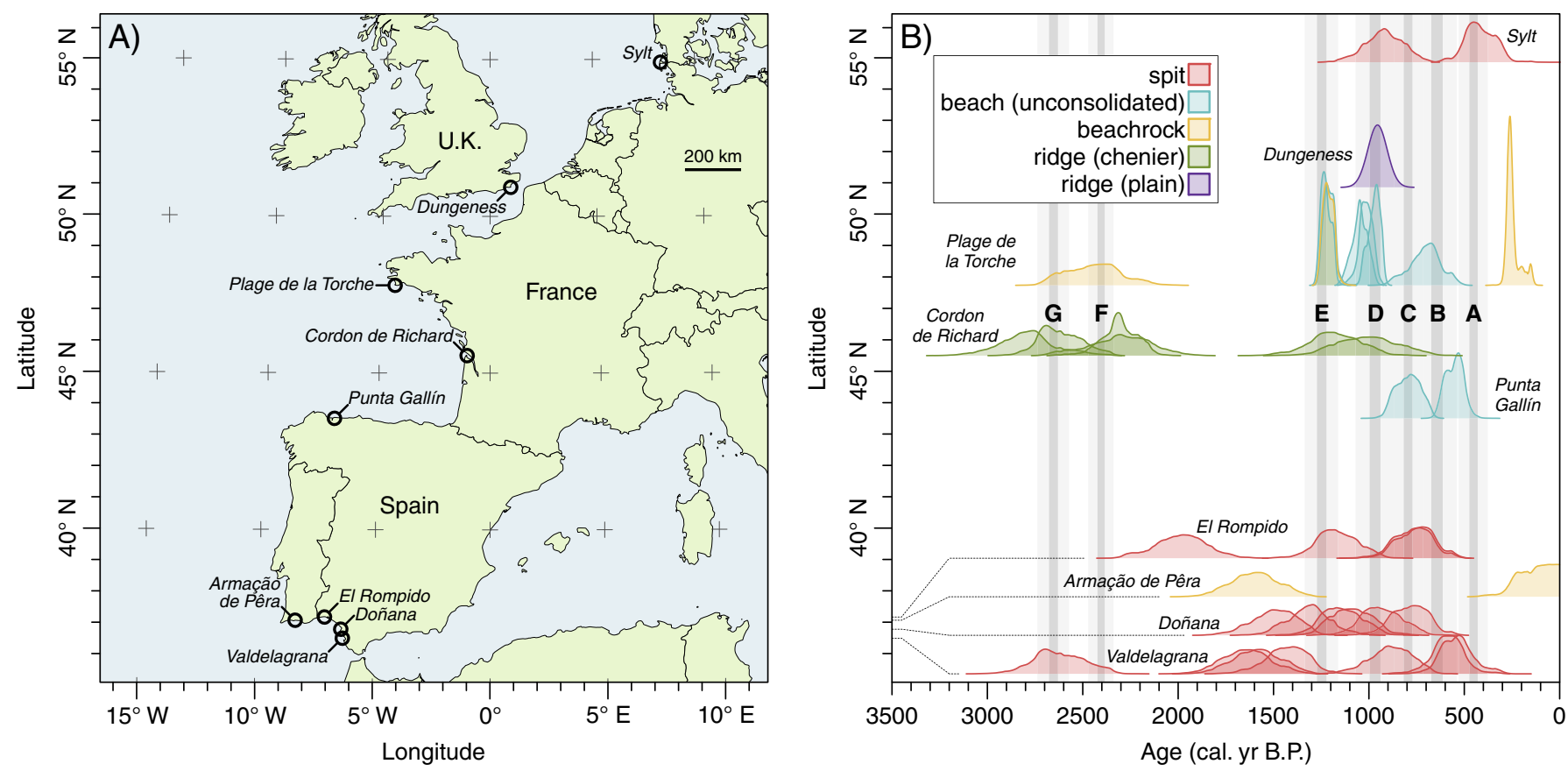

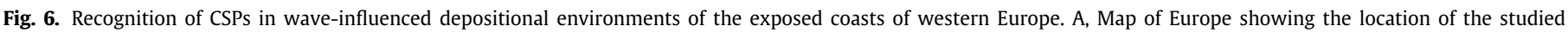

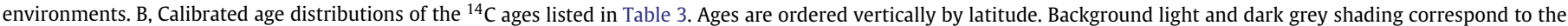
CSP $2 \sigma$ and $1 \sigma$ age ranges, respectively (Table 3 ).

adjacent deltas (e.g. Guadiana and Guadalquivir) driven by human activities and changes in precipitation regimes (Lario et al., 1995).

Local effects may indeed play a role in the Cadix Gulf, as well as in other areas considered here, but the overall difference between northern and southern Europe (Fig. 6) is more likely explained by spatial variability in wave climate across the North Atlantic Ocean. Spatially-explicit correlations between the NAO index and wave height show a marked north-south dipole pattern. Transition area of zero correlation occurs at the northwestern corner of Spain, around $43^{\circ} \mathrm{N}$ (Fig. 6A; Martínez-Asensio et al., 2016). Southwards of this limit, for instance in the Cadix Gulf, wave height decreases with positive NAO conditions. The combined influence of low-frequency storminess and high-frequency NAO variability, which likely drives the occurrence of CSPs in the Pertuis Charentais and elsewhere in northern Europe, is therefore not valid for this area. This opposite north/south pattern does not exist for the EA/WR index (Martínez-Asensio et al., 2016).

\subsection{Uncertainties and perspectives}

The present study raised a number of questions that would merit further consideration. As shown above, the EA/WR atmospheric circulation pattern seems to be an important driver of the occurrence of CSPs. We used (Conroy et al., 2017) lake record of summer (JJAS) precipitation rates over southern Tibet as an indirect proxy of the long-term EA/WR variability, but the influence of EA/WR on wave climate of the Pertuis Charentais predominates in winter (DJF; Poirier et al., 2017). With a sampling resolution of 25 years, it could be expected that this lake record provides a smoothed, long term-averaged reconstruction of the EA/WR circulation pattern. Further work is however needed to determine to which extent it can be reliably used as a proxy of the winter EA/WR during the late Holocene. Sediment records, speleothems or tree ring data recovered from the EA/WR poles of action, in western Europe and central Asia (Barnston and Livezey, 1987), might be useful to check this hypothesis.

Reservoir age of the water masses on the northern Icelandic shelf $\left(65^{\circ} \mathrm{N}\right)$ varied by \pm 150 years since about $1300 \mathrm{cal}$. yr B.P., depending on the strength of the North Atlantic Current (NAC; Wanamaker Jr et al., 2012). Feedbacks between the NAC and the NAO atmospheric circulation pattern have also influenced $\Delta \mathrm{R}$ along French Atlantic coasts between 1885 and 1950 CE by 90 to 170 years (Tisnérat-Laborde et al., 2010). In the present study, such changes in the $\Delta R$ parameter were not considered for calibrating the ${ }^{14} \mathrm{C}$ ages (Table 2), which could have an impact on the chronological boundaries of CSPs. The overall good agreement between CSPs and late Holocene climate changes in the North Atlantic Ocean suggests that this impact is probably minor, but additional data would help to raise this uncertainty.

Definition of CSPs F and G in the Pertuis Charentais mainly relied on ${ }^{14} \mathrm{C}$ dates with a large dating error (scintillation method; Table 1 ). New data may help to evaluate more precisely the chronological boundaries of CSPs that could have occurred during the penultimate period of decreased storminess, from about 2000 to 2700 cal. yr B.P. (Fig. 5).

Additional geochronological studies should also be carried out along the coasts of western Europe, in order to better constrain the spatial and temporal extent of the CSPs evidenced in the Pertuis Charentais. Dating of beachrocks should be avoided, as carbonate cementation involved in their formation has complex, multifactorial causes controlled by water temperature, $\mathrm{pH}$, salinity, dissolved ions, organic matter and bacteria, to name but a few (Vousdoukas et al., 2007). This could explain the overall low agreement between CSP age ranges and ${ }^{14} \mathrm{C}$ dates obtained on beachrocks in Plage de la Torche (France) and Armação de Pêra (Portugal, $37^{\circ} \mathrm{N}$ ), the latter being moreover located in the negative NAO-wave height correlation area. 


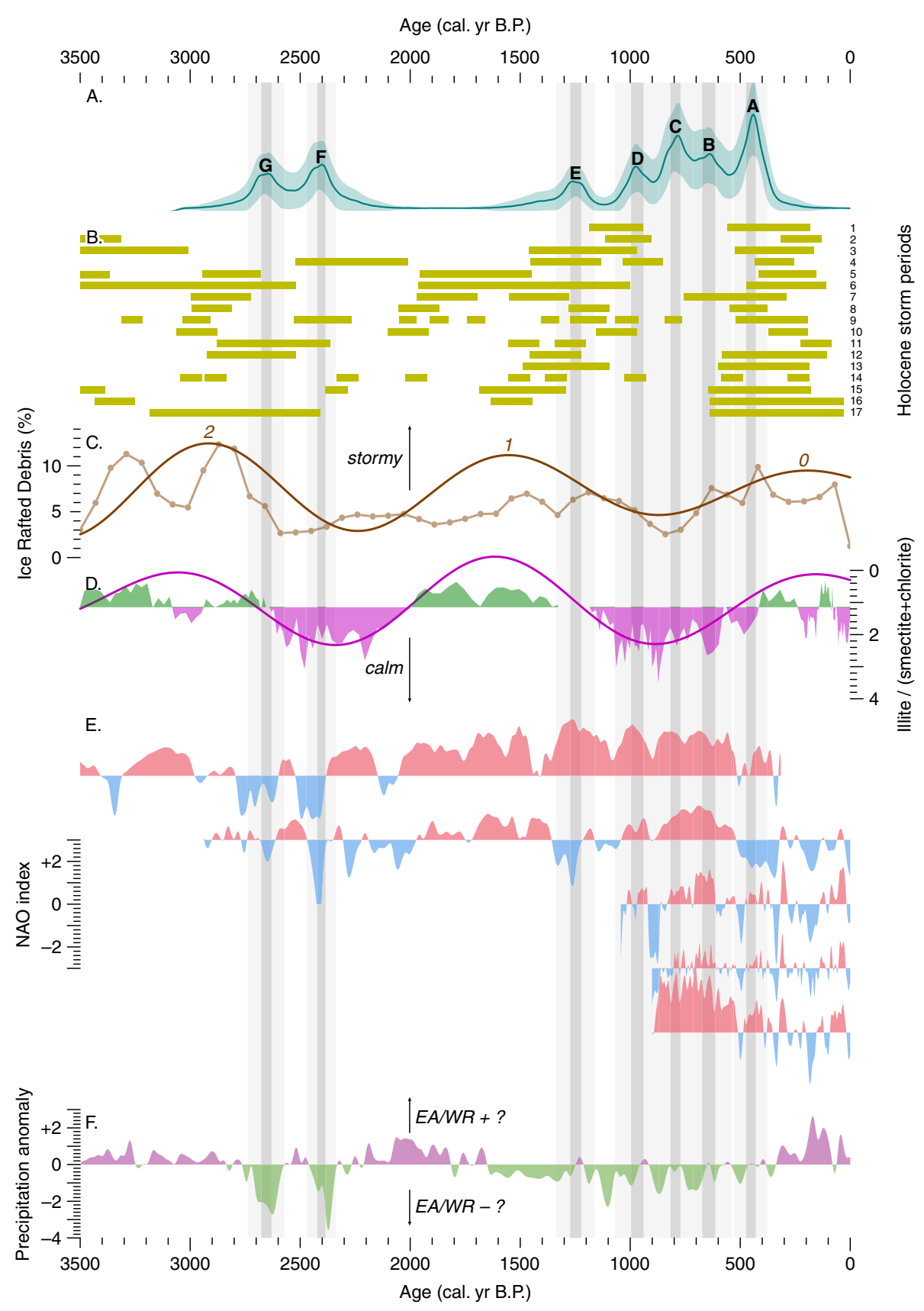

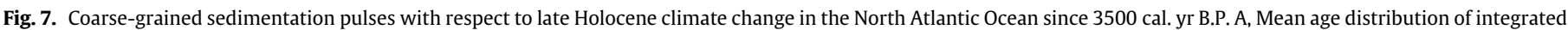

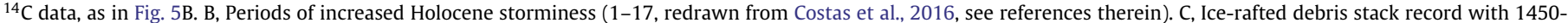

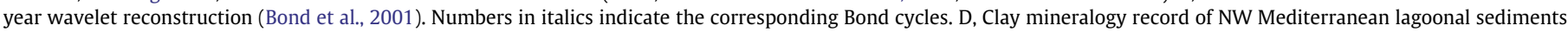

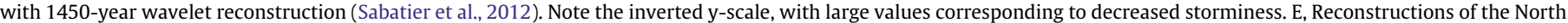

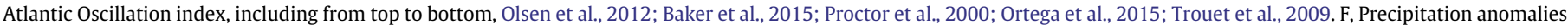

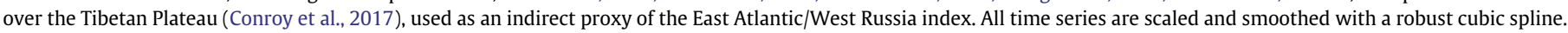
Background light and dark grey shading correspond to the CSP $2 \sigma$ and $1 \sigma$ age ranges, respectively (Table 3 ).

\section{Conclusions}

Compilation of existing ${ }^{14} \mathrm{C}$ data performed on coarse-grained sediment bodies of the Pertuis Charentais helped to better understand the temporal trends in high-energy marine sedimentation along coasts of the northeastern Atlantic Ocean, between the so-called Holocene Storm Periods. CSPs are defined as periods of increased accumulation of coarse-grained sediment particles identified in the study area, and possibly in other wave-exposed environments of western Europe, above $43^{\circ} \mathrm{N}$. In first order, the occurrence of CSPs is likely controlled by the 1450-yr cycle of North Atlantic storminess. Decreased frequency and/or intensity of erosive storm events is interpreted to allow the deposition and long-term preservation of coarse-grained sediment deposits. In second order, the occurrence of CSPs is likely controlled by changes in the North Atlantic wave climate, driven by low-frequency variability in the NAO and EA/WR atmospheric circulation patterns. Combination of positive NAO and negative EA/WR conditions is known to induce 
more energetic waves across the North Atlantic Ocean. Such conditions are therefore expected to increase transport of coarse-grained sediments to the coast, contributing to the formation of coastal barriers. Although spatially restricted, our data highlight the complex climate control on sediment supply and preservation on the edification of marine coastal barriers. Our results confirm that the Pertuis Charentais have the potential to record climate changes that occurred during the late Holocene with reasonable accuracy. Results also suggest that the chronological boundaries of CSPs, as opposed to that of HSPs, could be used as a diagnostic tool to differentiate storm deposits indicative of sudden, episodic high-energy sedimentation, from marine sediment bodies resulting from the sustained action of higher-than-average wave-induced sediment transport. They could also provide additional support in the interpretation of late Holocene coastal paleoenvironments. Integration of existing and new geochronological data obtained on coarse-grained sediment bodies of western European coasts may help to better constrain CSPs in space and time.

\section{Acknowledgements}

The authors wish to thank two anonymous reviewers for their constructive comments that substantially helped to improve the quality of the manuscript. This work is a contribution to the BLiNiS research project (2013-2014). Financial support was provided by the French Ministry of Environment (Ministère de l'Ecologie, du Développement Durable et de l'Energie, MEDDE) through the LITEAU funding scheme. Geospatial datasets (aerial photographs, topographic models) owned by the Institut Géographique National IGN were used in accordance with data license agreement attributed to C.P. and B.T. host institution. Non-commercial use of geological maps owned by the Bureau de Recherches Géologiques et Minières BRGM, including those outside the public domain, is allowed by French transcription of European Union Directive 2003/98/CE related to freedom of access and reuse of public information and data. The authors warmly thank Dr. Valerie Trouet (University of Arizona) for her dedication to an attempted development of a tree-ring based millennium reconstruction of the EA/WR atmospheric circulation pattern.

\section{References}

Alexanderson, H., Bernhardson, M., 2016. OSL dating and luminescence characteristics of aeolian deposits and their source material in Dalarna, central Sweden. Boreas 45 (4), 876-893. http://dx.doi.org/10.1111/bor.12197.

Allard, J., Bertin, X., Chaumillon, E., Pouget, F., 2008. Sand spit rhythmic development: a potential record of wave climate variations? Arçay Spit, western coast of France. Mar. Geol. 253 (3-4), 107-131. http://dx.doi.org/10.1016/j.margeo.2008.05.009.

Allard, J., Chaumillon, E., Bertin, X., Poirier, C., Ganthy, F., 2010. Sedimentary record of environmental changes and human interferences in a macrotidal bay for the last millenaries: the Marennes-Oléron Bay (SW France). Bull. Soc. Geol. Fr. 181 (2), 151-169. http://dx.doi.org/10.2113/gssgfbull.181.2.151.

Allroggen, N., Tronicke, J., Delock, M., Böniger, U., 2015. Topographic migration of 2D and 3D ground-penetrating radar data considering variable velocities. Near Surf. Geophys. 13 (3), 253-259. http://dx.doi.org/10.3997/1873-0604.2014037.

Anonymous, 1997. Borehole BSS001RLCA (Banque du Sous-Sol). Bureau de Recherches Géologiques et Minières. (techreport). http://ficheinfoterre.brgm.fr/ InfoterreFiche/ficheBss.action?id=BSS001RLCA.

Baker, A., Hellstrom, J.C., Kelly, B.F.J., Mariethoz, G., Trouet, V., 2015. A composite annual-resolution stalagmite record of North Atlantic climate over the last three millennia. Sci. Rep. 5 (1). http://dx.doi.org/10.1038/srep10307.

Baltzer, A., Walter-Simonnet, A.-V., Mokeddem, Z., Tessier, B., Goubert, E., Cassen, S. Diffo, A., 2014. Climatically-driven impacts on sedimentation processes in the Bay of Quiberon (south Brittany, France) over the last 10,000 years. The Holocene 24 (6), 679-688. http://dx.doi.org/10.1177/0959683614526933.

Barnston, A.G., Livezey, R.E., 1987. Classification, seasonality and persistence of lowfrequency atmospheric circulation patterns. Mon. Weather Rev. 115, 1086-1126. http://dx.doi.org/10.1175/1520-0493(1987)115<1083:CSAPOL > 2.0.CO;2.

Barusseau, J.-P., 1967. Sur la minéralogie de la fraction lourde des alluvions sableuses des Pertuis Charentais (Pertuis d'Antioche et Pertuis Breton). Bull. Assoc. Fr. Etud Quaternaire 4 (2), 135-143. http://dx.doi.org/10.3406/quate.1967.1056.
Bateman, M.D., Godby, S.P., 2004. Late-Holocene inland dune activity in the UK: a case study from Breckland, East Anglia. The Holocene 14 (4), 579-588. http://dx.doi. org/10.1191/0959683604hl735rp.

Baumann, J., Chaumillon, E., Bertin, X., Schneider, J.-L., Guillot, B., Schmutz, M., 2017. Importance of infragravity waves for the generation of washover deposits. Mar. Geol. 391, 20-35. http://dx.doi.org/10.1016/j.margeo.2017.07.013.

Baumann, J., Chaumillon, E., Schneider, J.-L., Jorissen, F., Sauriau, P.-G., Richard, P. Bonnin, J., Schmidt, S., 2017. Contrasting sediment records of marine submersion events related to wave exposure, Southwest France. Sediment. Geol. 353, 158-170. http://dx.doi.org/10.1016/j.sedgeo.2017.03.009.

Bertin, X., Castelle, B., Chaumillon, E., Butel, R., Quique, R., 2008. Longshore transport estimation and inter-annual variability at a high-energy dissipative beach: St. Trojan beach, SW Oléron Island, France. Cont. Shelf Res. 28 (10-11), 1316-1332. http://dx.doi.org/10.1016/j.csr.2008.03.005.

Bertin, X., Chaumillon, E., 2006. The implication of oyster farming in increasing sedimentation rates in a macrotidal bay: the Marennes-Oléron Bay, France. Cah. Biol. Mar. 47, 19-22.

Bertin, X., Chaumillon, E., Weber, N., Tesson, M., 2004. Morphological evolution and time-varying bedrock control of main channel at a mixed energy tidal inlet: Maumusson Inlet, France. Mar. Geol. 204 (1-2), 187-202. http://dx.doi.org/10. 1016/s0025-3227(03)00353-0.

Billeaud, I., Chaumillon, E., Weber, O., 2005. Evidence of a major environmental change recorded in a macrotidal bay (Marennes-Oleron Bay, France) by correlation between VHR seismic profiles and cores. Geo-Mar. Lett. 25 (1), 1-10. http:// dx.doi.org/10.1007/s00367-004-0183-0.

Billeaud, I., Tessier, B., Lesueur, P., 2009. Impacts of late Holocene rapid climate changes as recorded in a macrotidal coastal setting (Mont-Saint-Michel Bay, France). Geology 37 (11), 1031-1034. http://dx.doi.org/10.1130/g30310a.1.

Biteau, J.-J., Marrec, A.L., Vot, M.L., Masset, J.-M., 2006. The Aquitaine Basin. Pet. Geosci. 12 (3), 247-273. http://dx.doi.org/10.1144/1354-079305-674.

Björck, S., Clemmensen, L.B., 2004. Aeolian sediment in raised bog deposits, Halland, SW Sweden: a new proxy record of Holocene winter storminess variation in southern Scandinavia? The Holocene 14 (5), 677-688. http://dx.doi.org/10.1191/ 0959683604hl746rp.

Bond, G., Kromer, B., Beer, J., Muscheler, R., Evans, M.N., Showers, W., Hoffmann, S., Lotti-Bond, R., Hajdas, I., Bonani, G., 2001. Persistent solar influence on North Atlantic climate during the Holocene. Science 294 (5549), 2130-2136. http://dx. doi.org/10.1126/science.1065680.

Bourgueil, B., Moreau, P., Dubreuilh, J., 1976. Carte géologique de la France à 1/50 000, feuille 657, Ile d'Oléron. http://ficheinfoterre.brgm.fr/Notices/0657N.pdf.

Bourgueil, B., Moreau, P., Dubreuilh, J., Vouvé, J., 1976. Carte géologique de la France à 1/50 000, feuille 681, Marennes. http://ficheinfoterre.brgm.fr/Notices/0681N. pdf.

Bourgueil, B., Moreau, P., Gabet, C., L'Homer, A., Vouvé, J., 1972. Carte géologique de la France à 1/50 000, feuille 658, Rochefort. http://ficheinfoterre.brgm.fr/Notices/ 0658 N.pdf.

Breilh, J.-F., Bertin, X., Chaumillon, E., Giloy, N., Sauzeau, T., 2014. How frequent is storm-induced flooding in the central part of the Bay of Biscay? Global Planet. Change 122, 161-175. http://dx.doi.org/10.1016/j.gloplacha.2014.08.013.

Breilh, J.F., Chaumillon, E., Bertin, X., Gravelle, M., 2013. Assessment of static flood modeling techniques: application to contrasting marshes flooded during Xynthia (western France). Nat. Hazards Earth Syst. Sci. 13 (6), 1595-1612. http://dx.doi. org/10.5194/nhess-13-1595-2013.

Carbonel, P., Dartevelle, H., Evin, J., Gruet, Y., Laporte, L., Marambat, L., Tastet, J.P. Vella, C., Weber, O, 1998. Evolution paléogéographique de l'estuaire de la Charente au cours de l'Holocène. In: Laporte, L. (Ed.), L'estuaire De La Charente De La Protohistoire Au Moyen Age. Documents d'Archéologie Française 72. Maison des Sciences de l'Homme, Paris, pp. 15-25.

Chaumillon, E., Bertin, X., Fortunato, A.B., Bajo, M., Schneider, J.-L., Dezileau, L., Walsh, J.P., Michelot, A., Chauveau, E., Créach, A., Hénaff, A., Sauzeau, T., Waeles, B., Gervais, B., Jan, G., Baumann, J., Breilh, J.-F., Pedreros, R., 2017. Storm-induced marine flooding: lessons from a multidisciplinary approach. Earth Sci. Rev. 165 151-184. http://dx.doi.org/10.1016/j.earscirev.2016.12.005.

Chaumillon, E., Proust, J.-N., Menier, D., Weber, N., 2008. Incised-valley morphologies and sedimentary-fills within the inner shelf of the Bay of Biscay (France): a synthesis. J. Mar. Syst. 72 (1-4), 383-396. http://dx.doi.org/10.1016/j.jmarsys.2007. 05.014 .

Chaumillon, E., Tessier, B., Reynaud, J.-Y., 2010. Stratigraphic records and variability of incised valleys and estuaries along French coasts. Bull. Soc. Geol. Fr. 181 (2), 75-85. http://dx.doi.org/10.2113/gssgfbull.181.2.75

Chaumillon, E., Tessier, B., Weber, N., Tesson, M., Bertin, X., 2004. Buried sandbodies within present-day estuaries (Atlantic coast of France) revealed by very high resolution seismic surveys. Mar. Geol. 211 (3-4), 189-214. http://dx.doi.org/10.1016/ j.margeo.2004.07.004.

Chaumillon, E., Weber, N., 2006. Spatial variability of modern incised valleys on the French Atlantic coast: comparison between the Charente and the Lay-Sèvre incised valleys. Incised Valleys in Time and Space. 85. Society for Sedimentary Geology., pp. 57-85. http://dx.doi.org/10.2110/pec.06.85.0057.

Clarke, M., Rendell, H., Tastet, J.-P., Clavé, B., Massé, L., 2002. Late-Holocene sand invasion and North Atlantic storminess along the Aquitaine Coast southwest France. The Holocene 12 (2), 231-238. http://dx.doi.org/10.1191/ 0959683602hl539rr.

Clarke, M.L. Rendell, H.M. 2006. Effects of storminess, sand supply and the North Atlantic Oscillation on sand invasion and coastal dune accretion in western Portugal. The Holocene 16 (3), 341-355. http://dx.doi.org/10.1191/ 0959683606hl932rp. 
Clavé, B., 2001. EVolution des paléo-environnements côtiers à l'Holocène : exemple de l'Aquitaine septentrionale. Ph.D. Thesis, Université Bordeaux I.

Clavé, B., Massé, L., Carbonel, P., Tastet, J.-P., 2001. Holocene coastal changes and infilling of the La Perroche marsh (French Atlantic coast). Oceanol. Acta 24 (4), 377-389. http://dx.doi.org/10.1016/s0399-1784(01)01153-7.

Clemmensen, L.B., Andreasen, F., Nielsen, S.T., Sten, E., 1996. The late Holocene coastal dunefield at Vejers, Denmark: characteristics, sand budget and depositional dynamics. Geomorphology 17 (1-3), 79-98. http://dx.doi.org/10.1016/ 0169-555x(95)00096-n.

Clemmensen, L.B., Murray, A., 2006. The termination of the last major phase of aeolian sand movement, coastal dunefields, Denmark. Earth Surf. Process. Landf. 31 (7), 795-808. http://dx.doi.org/10.1002/esp.1283.

Clemmensen, L.B., Murray, A., Heinemeier, J., de Jong, R., 2009. The evolution of Holocene coastal dunefields, Jutland, Denmark: a record of climate change over the past 5000 years. Geomorphology 105 (3-4), 303-313. http://dx.doi.org/10. 1016/j.geomorph.2008.10.003.

Conroy, J.L., Hudson, A.M., Overpeck, J.T., Liu, K.-B., Wang, L., Cole, J.E., 2017. The primacy of multidecadal to centennial variability over late-Holocene forced change of the Asian Monsoon on the southern Tibetan Plateau. Earth Planet. Sci. Lett. 458, 337-348. http://dx.doi.org/10.1016/j.epsl.2016.10.044.

Costas, S., Brito, P., FitzGerald, D., Goble, R., 2013. Climate-driven episodes of dune mobilization and barrier growth along the central coast of Portugal. Geol. Soc. Lond., Spec. Publ. 388 (1), 407-427. http://dx.doi.org/10.1144/sp388.6.

Costas, S., Jerez, S., Trigo, R.M., Goble, R., Rebêlo, L., 2012. Sand invasion along the Portuguese coast forced by westerly shifts during cold climate events. Quat. Sci. Rev. 42, 15-28. http://dx.doi.org/10.1016/j.quascirev.2012.03.008.

Costas, S., Naughton, F., Goble, R., Renssen, H., 2016. Windiness spells in SW Europe since the last glacial maximum. Earth Planet. Sci. Lett. 436, 82-92. http://dx.doi. org/10.1016/j.epsl.2015.12.023.

Dabrin, A., Schfer, J., Bertrand, O., Masson, M., Blanc, G., 2014. Origin of suspended matter and sediment inferred from the residual metal fraction: application to the Marennes Oleron Bay, France. Cont. Shelf Res. 72, 119-130. http://dx.doi.org/10. 1016/j.csr.2013.07.008.

Darby, D.A., Ortiz, J.D., Grosch, C.E., Lund, S.P., 2012. 1500-year cycle in the Arctic Oscillation identified in Holocene Arctic sea-ice drift. Nat. Geosci. 5 (12), 897-900. http://dx.doi.org/10.1038/ngeo1629.

de Jong, R., Björck, S., Björkman, L., Clemmensen, L.B., 2006. Storminess variation during the last 6500 years as reconstructed from an ombrotrophic peat bog in Halland, southwest Sweden. J. Quat. Sci. 21 (8), 905-919. http://dx.doi.org/10. $1002 /$ jqs.1011.

de Jong, R., Schoning, K., Björck, S., 2007. Increased aeolian activity during humidity shifts as recorded in a raised bog in south-west Sweden during the past 1700 years. Clim. Past 3 (3), 411-422. http://dx.doi.org/10.5194/cp-3-411-2007.

Debret, M., Bout-Roumazeilles, V., Grousset, F., Desmet, M., McManus, J.F., Massei, N. Sebag, D., Petit, J.-R., Copard, Y., Trentesaux, A., 2007. The origin of the $1500-$ year climate cycles in Holocene North-Atlantic records. Clim. Past 3 (4), 569-575. http://dx.doi.org/10.5194/cp-3-569-2007.

Decker, I., Strat, P.L., Karnay, G., Bourgine, B., Vairon, J., 2001. Géométries et dynamique de remblayage de l'incision holocène dans le marais de Rochefort : modélisation géologique. Tech. Rep. RP-51007-FR. Bureau de Recherches Géologiques et Minières.,

Degeai, J.-P., Devillers, B., Dezileau, L., Oueslati, H., Bony, G., 2015. Major storm periods and climate forcing in the Western Mediterranean during the Late Holocene. Quat. Sci. Rev. 129, 37-56. http://dx.doi.org/10.1016/j.quascirev.2015.10.009.

Delibrias, G., Guillier, M.-T., Labeyrie, J., 1974. Gif natural radiocarbon measurements VIII. Radiocarbon 16 (1), 15-94

Delibrias, G., Guillier, M.-T., Labeyrie, J., 1982. Gif natural radiocarbon measurements IX. Radiocarbon 24 (3), 291-343.

Dezileau, L., Sabatier, P., Blanchemanche, P., Joly, B., Swingedouw, D., Cassou, C., Castaings, J., Martinez, P., Grafenstein, U.V., 2011. Intense storm activity during the Little Ice Age on the French Mediterranean coast. Palaeogeogr. Palaeoclimatol. Palaeoecol. 299 (1-2), 289-297. http://dx.doi.org/10.1016/j.palaeo.2010.11.009.

Dobrynin, M., Murawsky, J., Yang, S., 2012. Evolution of the global wind wave climate in CMIP5 experiments. Geophys. Res. Lett. 39 (18). http://dx.doi.org/10.1029/ 2012 gl052843.

Dujardin, J.-R., Bano, M., 2013. Topographic migration of GPR data: examples from Chad and Mongolia. Compt. Rendus Geosci. 345 (2), 73-80. http://dx.doi.org/10. 1016/j.crte.2013.01.003.

Feal-Pérez, A., Blanco-Chao, R., Ferro-Vázquez, C., Martínez-Cortizas, A., Costa-Casais, M., 2014. Late-Holocene storm imprint in a coastal sedimentary sequence (Northwest Iberian coast). The Holocene 24 (4), 477-488. http://dx.doi.org/10.1177/ 0959683613520257.

Ferrer, P., Benabdellouahed, M., Certain, R., Tessier, B., Barusseau, J.P., Bouchette, F., 2010. The Late Holocene sediment infilling and beach barrier dynamics of the Thau lagoon (Gulf of Lions, Mediterranean sea, SE France). Bull. Soc. Geol. Fr. 181 (2), 197-209. http://dx.doi.org/10.2113/gssgfbull.181.2.197.

Fraley, C., Raferty, A.E., 2002. Model-based clustering, discriminant analysis, and density estimation. J. Am. Stat. Assoc. 97 (458), 611-631. http://dx.doi.org/10.1198/ 016214502760047131.

Gabet, C., 1981. Note sur la formation du marais des Salines, commune de St Georges d'Oléron. Roccafortis 4 (8), 245-252.

Gilbertson, D., Schwenninger, J.-L., Kemp, R., Rhodes, E., 1999. Sand-drift and soil formation along an exposed North Atlantic coastline: 14,000 years of diverse geomorphological, climatic and human impacts. J. Archaeol. Sci. 26 (4), 439-469. http://dx.doi.org/10.1006/jasc.1998.0360.

Giot, P.-R., 1981. Chronique de préhistoire et de protohistoire finistérienne pour 1980. Bulletin de la Socié,té Archéologique du Finistère 109, 9-15.
Giot, P.-R., 1998. La dune ancienne de la baie d'Audierne. Norois 179 (1), 487-494. http://dx.doi.org/10.3406/noroi.1998.6889.

Gruet, Y., Sauriau, P.-G., 1994. Paléoenvironnements holocènes du Marais Poitevin (Littoral atlantique, France): reconstitution d'après les peuplements malacologiques. Quaternaire 5 (2), 85-94. http://dx.doi.org/10.3406/quate.1994.2018.

Hantzpergue, P., 1988. Carte géologique de la France à $1 / 50000$, feuille 633, La Rochelle - Ile de Ré. http://ficheinfoterre.brgm.fr/Notices/0633N.pdf.

Haslett, J., Parnell, A., 2008. A simple monotone process with application to radiocarbon-dated depth chronologies. J. R. Stat. Soc. Ser. C. Appl. Stat. 57 (4), 399-418. http://dx.doi.org/10.1111/j.1467-9876.2008.00623.x.

Ionita, M., 2014. The impact of the East Atlantic/Western Russia pattern on the hydroclimatology of Europe from mid-winter to late spring. Climate 2 (4), 296-309. http://dx.doi.org/10.3390/cli2040296.

Jackson, M.G., Oskarsson, N., Trønnes, R.G., McManus, J.F., Oppo, D.W., Grönvold, K. Hart, S.R., Sachs, J.P., 2005. Holocene loess deposition in Iceland: evidence for millennial-scale atmosphere-ocean coupling in the North Atlantic. Geology 33 (6), 509. http://dx.doi.org/10.1130/g21489.1.

Jelgersma, S., Stive, M., van der Valk, L., 1995. Holocene storm surge signatures in the coastal dunes of the western Netherlands. Mar. Geol. 125 (1-2), 95-110. http:// dx.doi.org/10.1016/0025-3227(95)00061-3.

Krichak, S.O., Alpert, P., 2005. Decadal trends in the East Atlantic-West Russia pattern and Mediterranean precipitation. Int. J. Climatol. 25 (2), 183-192. http://dx.doi. org/10.1002/joc. 1124 .

Kylander, M.E., Martínez-Cortizas, A., Bindler, R., Greenwood, S.L., Mörth, C.-M., Rauch, S., 2016. Potentials and problems of building detailed dust records using peat archives: an example from Store Mosse (the 'Great Bog'), Sweden. Geochim. Cosmochim. Acta 190, 156-174. http://dx.doi.org/10.1016/j.gca.2016.06.028.

Lamb, H.H., Frydendahl, K., 1991. HIstoric storms of the North Sea, British Isles and Northwest Europe. Cambridge University Press.

Lambeck, K., 1997. Sea-level change along the French Atlantic and Channel coasts since the time of the Last Glacial Maximum. Palaeogeogr. Palaeoclimatol. Palaeoecol. 129 (1-2), 1-22. http://dx.doi.org/10.1016/s0031-0182(96)00061-2.

Lario, J., Zazo, C., Dabrio, C.-J., Somoza, L., Goy, J.-L., Bardají, T., Silva, P.-G., 1995. Record of recent Holocene sediment input on spit bars and deltas of south Spain. J. Coast. Res. Spec. Issue 17, 241-245.

Lim, Y.-K., 2015. The East Atlantic/West Russia (EA/WR) teleconnection in the North Atlantic: climate impact and relation to Rossby wave propagation. Climate Dynam. 44, 3211-3222. http://dx.doi.org/10.1007/s00382-014-2381-4.

Lindhorst, S., Fürstenau, J., Hass, H.C., Betzler, C., 2010. Anatomy and sedimentary model of a hooked spit (Sylt, southern North Sea). Sedimentology 57 (4), 935-955. http://dx.doi.org/10.1111/j.1365-3091.2009.01126.x.

Martínez-Asensio, A., Tsimplis, M.N., Marcos, M., Feng, X., Gomis, D., Jordà, G., Josey, S.A., 2016. Response of the North Atlantic wave climate to atmospheric modes of variability. Int. J. Climatol. 36, 1210-1225. http://dx.doi.org/10.1002/joc.4415.

Masselink, G., van Heteren, S., 2014. Response of wave-dominated and mixed-energy barriers to storms. Mar. Geol. 352, 321-347. http://dx.doi.org/10.1016/j.margeo. 2013.11.004.

Morton, R.A., Sallenger, A.H., 2003. Morphological impacts of extreme storms on sandy beaches and barriers. J. Coast. Res. 19 (3), 560-573.

Moura, D., Veiga-Pires, C., Albardeiro, L., Boski, T., Rodrigues, A., Tareco, H., 2007. Holocene sea level fluctuations and coastal evolution in the central Algarve (southern Portugal). Mar. Geol. 237 (3-4), 127-142. http://dx.doi.org/10.1016/j. margeo.2006.10.026.

Nielsen, P.R., Dahl, S.O., Jansen, H.L., 2016. Mid- to late Holocene aeolian activity recorded in a coastal dunefield and lacustrine sediments on Andoya, northern Norway. The Holocene 26 (9), 1486-1501. http://dx.doi.org/10.1177/ 0959683616640050.

Olsen, J., Anderson, N.J., Knudsen, M.F., 2012. Variability of the North Atlantic Oscillation over the past 5200 years. Nat. Geosci. 5 (11), 808-812. http://dx.doi.org/10. 1038/ngeo1589.

Orme, L.C., Davies, S.J., Duller, G.A.T., 2015. Reconstructed centennial variability of Late Holocene storminess from Cors Fochno, Wales, UK. J. Quat. Sci. 30 (5), 478-488. http://dx.doi.org/10.1002/jqs.2792.

Orme, L.C., Reinhardt, L., Jones, R.T., Charman, D.J., Barkwith, A., Ellis, M.A., 2016 Aeolian sediment reconstructions from the Scottish Outer Hebrides: late Holocene storminess and the role of the North Atlantic Oscillation. Quat. Sci. Rev. 132, 15-25. http://dx.doi.org/10.1016/j.quascirev.2015.10.045.

Ortega, P., Lehner, F., Swingedouw, D., Masson-Delmotte, V., Raible, C.C., Casado M., Yiou, P., 2015. A model-tested North Atlantic Oscillation reconstruction for the past millennium. Nature 523 (7558), 71-74. http://dx.doi.org/10.1038/ nature 14518 .

Parnell, A.C., Haslett, J., Allen, J., Buck, C., Huntley, B., 2008. A flexible approach to assessing synchroneity of past events using Bayesian reconstructions of sedimentation history. Quat. Sci. Rev. 27 (19-20), 1872-1885. http://dx.doi.org/10.1016/j. quascirev.2008.07.009.

Parra, M., Trouky, H., Jouanneau, J.-M., Grousset, F., Latouche, C., Castaing, P., 1998. Etude isotopique (Sr-Nd) de l'origine des dépôts fins holocènes du littoral atlantique (S-O France). Oceanol. Acta 21 (5), 631-644. http://dx.doi.org/10.1016 s0399-1784(99)80022-x.

Platel, J.-P., Moreau, P., Vouvé, J., Debenath, A., Colmont, G.R., Gabet, C., 1976 Carte géologique de la France à 1/50 000, feuille 682, Saint-Agnant. http:// ficheinfoterre.brgm.fr/Notices/0682N.pdf.

Poirier, C., Chaumillon, E., Arnaud, F., 2011. Siltation of river-influenced coastal environments: respective impact of late Holocene land use and high-frequency climate changes. Mar. Geol. 290 (1-4), 51-62. http://dx.doi.org/10.1016/j.margeo. 2011.10.008. 
Poirier, C., Sauriau, P.-G., Chaumillon, E., Bertin, X., 2010. Influence of hydrosedimentary factors on mollusc death assemblages in a temperate mixed tideand-wave dominated coastal environment: implications for the fossil record. Cont. Shelf Res. 30 (17), 1876-1890. http://dx.doi.org/10.1016/j.csr.2010.08.015.

Poirier, C., Tessier, B., Chaumillon, E., Bertin, X., Fruergaard, M., Mouazé, D., Noël, S. Weill, P., Wöppelmann, G., 2017. Decadal changes in North Atlantic atmospheric circulation patterns recorded by sand spits since 1800 CE. Geomorphology 281 1-12. http://dx.doi.org/10.1016/j.geomorph.2016.12.028.

Pontee, N.I., Tastet, J.-P., Masse, L., 1998. Morpho-sedimentary evidence of Holocene coastal changes near the mouth of the Gironde and on the Medoc Peninsula SW France. Oceanol. Acta 21 (2), 243-261. http://dx.doi.org/10.1016/s03991784(98)80012-1.

Proctor, C.J., Baker, A., Barnes, W.L., Gilmour, M.A., 2000. A thousand year speleothem proxy record of North Atlantic climate from Scotland. Climate Dynam. 16 (10-11), 815-820. http://dx.doi.org/10.1007/s003820000077.

Rahmstorf, S., 2007. A semi-empirical approach to projecting future sea-level rise. Science 315 (5810), 368-370. http://dx.doi.org/10.1126/science.1135456.

Regrain, R., 1980. Géographie physique et télédétection des marais charentais. Paillard, Abbeville.

Reimer, P.J., Bard, E., Bayliss, A., Beck, J.W., Blackwell, P.G., Bronk Ramsey, C., Buck, C.E., Cheng, H., Edwards, R.L., Friedrich, M., Grootes, P.M., Guilderson, T.P., Haflidason, H., Hajdas, I., Hatté, C., Heaton, T.J., Hoffmann, D.L., Hogg, A.G., Hughen, K.A., Kaiser, K.F., Kromer, B., Manning, S.W., Niu, M., Reimer, R.W., Richards, D.A., Scott, E.M., Southon, J.R., Staff, R.A., Turney, C.S.M., van der Plicht, J., 2013. IntCal13 and Marine13 radiocarbon age calibration curves $0-50,000$ years cal BP. Radiocarbon 55 (04), 1869-1887. http://dx.doi.org/10.2458/azu\&uscore;js\& uscore;rc.55.16947.

Reimer, R.W., Reimer, P.J., 2006. Marine reservoir corrections and the calibration curve. PAGES News 14 (3), 12-13.

Roberts, H., Plater, A., 2007. Reconstruction of Holocene foreland progradation using optically stimulated luminescence (OSL) dating: an example from Dungeness, UK. The Holocene 17 (4), 495-505. http://dx.doi.org/10.1177| 0959683607077034

Rodríguez-Polo, S., Gracia, F.J., Benavente, J., del Río, L., 2009. Geometry and recent evolution of the Holocene beach ridges of the Valdelagrana littoral spit (Cádiz Bay, SW Spain). J. Coast. Res. Spec. Issue 56, 20-23.

Rogers, J.C., 1997. North Atlantic storm track variability and its association to the North Atlantic Oscillation and climate variability of Northern Europe. J. Clim. 10 (7), 1635-1647. http://dx.doi.org/10.1175/1520-0442(1997)010<1635 NASTVA $>2.0 . \mathrm{CO} ; 2$

Sabatier, P., Dezileau, L., Colin, C., Briqueu, L., Bouchette, F., Martinez, P., Siani, G., Raynal, O., Grafenstein, U.V., 2012. 7000 years of paleostorm activity in the NW Mediterranean Sea in response to Holocene climate events. Quatern. Res. 77 (01) 1-11. http://dx.doi.org/10.1016/j.yqres.2011.09.002.

Sabatier, P., Dezileau, L., Condomines, M., Briqueu, L., Colin, C., Bouchette, F., Duff, M.L., Blanchemanche, P., 2008. Reconstruction of paleostorm events in a coastal lagoon (Hérault, South of France). Mar. Geol. 251 (3-4), 224-232. http://dx.doi.org/10. 1016/j.margeo.2008.03.001

Sauriau, P.-G., Gruet, Y., 1988. Essai de reconstitution d'un paléoenvironnement marin récent dans le Marais Poitevin. Haliotis 18, 9-20.

Sibuet, J.-C., Srivastava, S.P., Spakman, W., 2004. Pyrenean orogeny and plate kinematics. J. Geophys. Res. Solid Earth Planets 109 (B8). http://dx.doi.org/10.1029/ 2003jb002514.

Sjögren, P., 2009. Sand mass accumulation rate as a proxy for wind regimes in the SW Barents Sea during the past $3 \mathrm{ka}$. The Holocene 19 (4), 591-598. http://dx.doi.org/ $10.1177 / 0959683609104033$

Sommerville, A., Hansom, J., Housley, R., Sanderson, D., 2007. Optically stimulated luminescence (OSL) dating of coastal aeolian sand accumulation in Sanday, Orkney Islands, Scotland. The Holocene 17 (5), 627-637. http://dx.doi.org/10. $1177 / 0959683607078987$.

Sorrel, P., Debret, M., Billeaud, I., Jaccard, S.L., McManus, J.F., Tessier, B., 2012. Persistent non-solar forcing of Holocene storm dynamics in coastal sedimentary archives. Nat. Geosci. 5 (12), 892-896. http://dx.doi.org/10.1038/ngeo1619.

Sorrel, P., Tessier, B., Demory, F., Delsinne, N., Mouazé, D., 2009. Evidence for millennial-scale climatic events in the sedimentary infilling of a macrotidal estuarine system, the Seine estuary (NW France). Quat. Sci. Rev. 28 (5-6), 499-516. http://dx.doi.org/10.1016/j.quascirev.2008.11.009.

Stéphan, P., Goslin, J., 2014. Evolution du niveau marin relatif à l'Holocène le long des côtes françaises de l'Atlantique et de la Manche : réactualisation des données par la méthode des sea-level index points. Quaternaire 25 (4), 295-312. http://dx.doi. org/10.4000/quaternaire.7269.

Tessier, B., Delsinne, N., Sorrel, P., 2010. Holocene sedimentary infilling of a tidedominated estuarine mouth. The example of the macrotidal Seine estuary (NW France). Bull. Soc. Geol. Fr. 181 (2), 87-98. http://dx.doi.org/10.2113/gssgfbull. 181.2.87.
Tessier, B., Poirier, C., Chaumillon, E., Weill, P., Mouazé, D., Bertin, X., Wöppelmann, G., Garnier, E., Noël, S., 2013. Dynamique des barrières littorales depuis le Petit Age Glaciaire : Reconstitutions stratigraphique, hydrodynamique et historique. $25^{\text {ème }}$ Congrès De Sédimentologie. 43. pp. 393.

Tisdall, E., McCulloch, R., Sanderson, D., Simpson, I., Woodward, N., 2013. Living with sand: a record of landscape change and storminess during the Bronze and Iron Ages Orkney, Scotland. Quat. Int. 308-309, 205-215. http://dx.doi.org/10.1016/j. quaint.2013.05.016.

Tisnérat-Laborde, N., Paterne, M., Métivier, B., Arnold, M., Yiou, P., Blamart, D., Raynaud, S., 2010. Variability of the northeast Atlantic sea surface $\Delta^{14} \mathrm{C}$ and marine reservoir age and the North Atlantic Oscillation (NAO). Quat. Sci. Rev. 29 (19-20), 2633-2646. http://dx.doi.org/10.1016/j.quascirev.2010.06.013.

Trouet, V., Esper, J., Graham, N.E., Baker, A., Scourse, J.D., Frank, D.C., 2009. Persistent positive North Atlantic Oscillation mode dominated the Medieval Climate Anomaly. Science 324 (5923), 78-80. http://dx.doi.org/10.1126/science. 1166349.

Trouet, V., Scourse, J., Raible, C., 2012. North Atlantic storminess and Atlantic Meridional Overturning Circulation during the last Millennium: reconciling contradictory proxy records of NAO variability. Global Planet. Change 84-85, 48-55. http://dx.doi.org/10.1016/j.gloplacha.2011.10.003.

van Hengstum, P.J., Donnelly, J.P., Kingston, A.W., Williams, B.E., Scott, D.B., Reinhardt E.G., Little, S.N., Patterson, W.P., 2015. Low-frequency storminess signal at Bermuda linked to cooling events in the North Atlantic region. Paleoceanography 30 (2), 52-76. http://dx.doi.org/10.1002/2014pa002662.

van Vliet-Lanoë, B., Goslin, J., Hénaff, A., Hallégouët, B., Delacourt, C., Le Cornec, E., Meurisse-Fort, M., 2016. Holocene formation and evolution of coastal dunes ridges, Brittany (France). Compt. Rendus Geosci. 348 (6), 462-470. http://dx.doi. org/10.1016/j.crte.2015.01.001.

van Vliet-Lanoë, B., Penaud, A., Hénaff, A., Delacourt, C., Fernane, A., Goslin, J., Hallégouët, B., Le Cornec, E., 2014. Middle- to late-Holocene storminess in Brittany (NW France): Part II - the chronology of events and climate forcing. The Holocene 24 (4), 434-453. http://dx.doi.org/10.1177/0959683613519688.

Verger, F., Bresson, G., Limasset, O., Barruol, J., 1975. Carte géologique de la France à $1 / 50000$, feuille 608, L'Aiguillon-sur-Mer. http://ficheinfoterre.brgm.fr/Notices/ 0608N.pdf.

Visset, L., 1987. Etude pollenanalytique de quelques sites du Marais Poitevin. Bull. Assoc. Fr. Etud. Quaternaire 24 (2), 81-91. http://dx.doi.org/10.3406/quate.1987.1836.

Visset, L., Voeltzel, D., Maisonneuve, E., Nikodic, J., Margerel, J.P., Borne, V., 1990. Paléoécologie holocène des Marais du Rocher en Maillezais (Vendée), dans le Marais Poitevin (Littoral Atlantique - France). Quaternaire 1 (2), 111-121. http:// dx.doi.org/10.3406/quate.1990.1928.

Vousdoukas, M.I., Velegrakis, A.F., Plomaritis, T.A., 2007. Beachrock occurrence, characteristics, formation mechanisms and impacts. Earth Sci. Rev. 85, 23-46. http:// dx.doi.org/10.1016/j.earscirev.2007.07.002.

Wanamaker, A.D., Jr, Butler, P.G., Scourse, J.D., Heinemeier, J., Eiríksson, J., 2012. Surface changes in the North Atlantic meridional overturning circulation during the last millennium. Nat. Commun. 3, 899. http://dx.doi.org/10.1038/ncomms1901.

Weber, N., Chaumillon, E., Tesson, M., 2004. Enregistrement de la dernière remontée du niveau marin dans l'architecture interne d'une vallée incisée : le pertuis Breton (Charente-Maritime). Compt. Rendus Geosci. 336 (14), 1273-1282. http://dx.doi. org/10.1016/j.crte.2004.07.007.

Weber, N., Chaumillon, E., Tesson, M., Garlan, T., 2004. Architecture and morphology of the outer segment of a mixed tide and wave-dominated-incised valley, revealed by HR seismic reflection profiling: the paleo-Charente River, France. Mar. Geol. 207 (1-4), 17-38. http://dx.doi.org/10.1016/j.margeo.2004.04.001.

Wilson, P., Braley, S.M., 1997. Development and age structure of Holocene coastal sand dunes at Horn Head, near Dunfanaghy, Co Donegal, Ireland. The Holocene 7 (2), 187-197. http://dx.doi.org/10.1177/095968369700700206.

Wilson, P., McGourty, J., Bateman, M.D., 2004. Mid- to late-Holocene coastal dune event stratigraphy for the north coast of Northern Ireland. The Holocene 14 (3), 406-416. http://dx.doi.org/10.1191/0959683604hl716rp.

Zazo, C., Goy, J.-L., Somoza, L., Dabrio, C.-J., Belluomini, G., Improta, S., Lario, J., Bardají, T., Silva, P.-G., 1994. Holocene sequence of sea-level fluctuations on relation to climatic trends in the Atlantic-Mediterranean linkage coast. J. Coast. Res. 10 (4), 933-945.

Zeeberg, J., 2008. The European sand belt in eastern Europe - and comparison of Late Glacial dune orientation with GCM simulation results. Boreas 27 (2), 127-139. http://dx.doi.org/10.1111/j.1502-3885.1998.tb00873.x.

Zhang, K., Leatherman, S., 2011. Barrier island population along the U.S. Atlantic and Gulf coasts. J. Coast. Res. 272, 356-363. http://dx.doi.org/10.2112/jcoastres-d10-00126.1.

Zhao, A., Jiang, Y., Wang, W., 2005. Signal-to-noise ratio enhancement in multichannel GPR data via the Karhunen-Loève transform. Progress in Electromagnetics Research Symposium. pp. 754-757. 